\title{
Aircraft observations of aerosol, cloud, precipitation, and boundary layer properties in pockets of open cells over the southeast Pacific
}

\author{
C. R. Terai, C. S. Bretherton, R. Wood, and G. Painter \\ Department of Atmospheric Sciences, University of Washington, Seattle, Washington, USA \\ Correspondence to: C. R. Terai (terai@atmos.washington.edu)
}

Received: 14 March 2014 - Published in Atmos. Chem. Phys. Discuss.: 26 March 2014

Revised: 27 June 2014 - Accepted: 1 July 2014 - Published: 13 August 2014

\begin{abstract}
Five pockets of open cells (POCs) are studied using aircraft flights from the VOCALS Regional Experiment (VOCALS-REx), conducted in October and November 2008 over the southeast Pacific Ocean. Satellite imagery from the geostationary satellite GOES-10 is used to distinguish POC areas, and measurements from the aircraft flights are used to compare aerosol, cloud, precipitation, and boundary layer conditions inside and outside of POCs. Conditions observed across individual POC cases are also compared.

POCs are observed in boundary layers with a wide range of inversion heights (1250 to $1600 \mathrm{~m})$ and surface wind speeds (5 to $11 \mathrm{~m} \mathrm{~s}^{-1}$ ) and show no remarkable difference from the observed surface and free-tropospheric conditions during the two months of the field campaign. In all cases, compared to the surrounding overcast region the POC boundary layer is more decoupled, supporting both thin stratiform and deeper cumulus clouds. Although cloud-base precipitation rates are higher in the POC than the overcast region in each case, a threshold precipitation rate that differentiates POC precipitation from overcast precipitation does not exist. Mean cloud-base precipitation rates in POCs can range from 1.7 to $5.8 \mathrm{~mm} \mathrm{~d}^{-1}$ across different POC cases. The occurrence of heavy drizzle ( $>0 \mathrm{dBZ}$ ) lower in the boundary layer better differentiates POC precipitation from overcast precipitation, likely leading to the more active cold pool formation in POCs. Cloud droplet number concentration is at least a factor of 8 smaller in the POC clouds, and the ratio of drizzle water to cloud water in POC clouds is over an order of magnitude larger than that in overcast clouds, indicating an enhancement of collision-coalescence processes in POC clouds.

Despite large variations in the accumulation-mode aerosol concentrations observed in the surrounding overcast region
\end{abstract}

( 65 to $324 \mathrm{~cm}^{-3}$ ), the accumulation-mode aerosol concentrations observed in the subcloud layer of all five POCs exhibit a much narrower range (24 to $40 \mathrm{~cm}^{-3}$ ), and cloud droplet concentrations within the cumulus updrafts originating in this layer reflect this limited variability. Above the POC subcloud layer exists an ultraclean layer with accumulationmode aerosol concentrations $<5 \mathrm{~cm}^{-3}$, demonstrating that in-cloud collision-coalescence processes efficiently remove aerosols. The existence of the ultraclean layer also suggests that the major source of accumulation-mode aerosols, and hence of cloud condensation nuclei in POCs, is the ocean surface, while entrainment of free-tropospheric aerosols is weak. The measurements also suggest that at approximately $30 \mathrm{~cm}^{-3}$ a balance of surface source and coalescence scavenging sinks of accumulation-mode aerosols maintain the narrow range of observed subcloud aerosol concentrations.

\section{Introduction}

During most of the year, a large stratocumulus cloud deck covers the southeast Pacific Ocean, extending westward from the South American continent. Due to a strong albedo and weak greenhouse effect, the stratocumulus exerts a strong cooling effect on the ocean and the atmospheric boundary layer (de Szoeke et al., 2012). The extensive stratocumulus cloud deck is occasionally interrupted by cloud breaks in the form of pockets of open cells, where the lower cloud cover exposes the darker sea surface, effectively lowering the albedo of the area where these features form.

Pockets of open cells (POCs) have previously been defined as regions of open-cell convection completely or largely embedded within a larger region of closed-cell convection 
(Stevens et al., 2005; Wood et al., 2008). In regions of opencell convection, patches of descending clear air are ringed by ascending cloudy air, giving it a honeycomb-like pattern when viewed from above. On the other hand, closed-cell convection are characterized by patches of cloudy ascending air that are ringed by clearer descending air, leading to higher albedos (Atkinson and Zhang, 1996; Wood and Hartmann, 2006). Subsequent studies have found, however, that POCs also support thin and extensive stratiform clouds in addition to the honeycomb-like patterns or isolated clusters of deeper cumulus clouds (Wood et al., 2011a) and that horizontal gradients in cloud microphysical properties exist at the transition from closed to open cellular convection, with often dramatic decreases in cloud droplet number concentrations inside the POCs (Stevens et al., 2005; Sharon et al., 2006; Wood et al., 2008, 2011a). In this paper, POCs are defined as regions of broken cumuliform convection, possibly overlaid by thin patchy stratocumulus, that (a) are embedded within regions of closed-cell stratocumulus clouds and (b) that also show cloud microphysical changes at the transition, evident in daytime satellite images as an increase in cloud effective radius at the POC edges. This stricter definition of POCs excludes instances of cloud break-up that accompany cloud thinning due to increased subsidence and evaporation, and also many cloud breaks at the western edge of stratocumulus cloud decks.

POCs have been observed in satellite imagery (Garay et al., 2004) and in various field experiments (Bretherton et al., 2004; Stevens et al., 2005; Sharon et al., 2006; Wood et al., 2011a; Cui et al., 2014). Because the cloud cover is relatively low in POCs, their formation can influence the amount of incident solar radiation that is absorbed at the Earth's surface. Up to $10-15 \%$ of the southeast Pacific region can be covered by POCs during October and November, which are months of extensive cloud cover (Wood et al., 2008). Although regional models have started to simulate episodic changes in cloud cover and albedo due to synoptic forcing (Abel et al., 2010) and transport of aerosol plumes from coastal pollution sources (Yang et al., 2011; Saide et al., 2012; George et al., 2013), models still do not clearly demonstrate the formation of reduced cloud cover in the form of POCs (Abel et al., 2010; Toniazzo et al., 2011). An exception exists for Mechem and Kogan (2003), who employed a nested $2 \mathrm{~km}$ resolution mesoscale model within a larger regional model to form drizzle-induced cloud break-up in overcast stratocumulus. The low aerosol concentrations observed within POCs (Petters et al., 2006; Sharon et al., 2006; Wood et al., 2008, 2011a) strongly suggest a mechanism by which aerosols affect clouds, and also suggest the need to incorporate aerosol-cloud interactions occurring on scales of a few kilometers and smaller to simulate POC formation in models.

Various aspects of the POCs have been convincingly simulated by large-eddy simulations (LES) and high-resolution, cloud-resolving simulations (Wang and Feingold, 2009a, b; Wang et al., 2010; Berner et al., 2011; Kazil et al., 2011;
Berner et al., 2013). Several of these studies initialize a region of the model domain with lower cloud droplet number concentration to initiate POC formation (e.g., Wang and Feingold, 2009a, b; Berner et al., 2011). The simulations point to the importance of cold pools in transforming closedcell circulation to open-cell circulation (Wang et al., 2010), and indicate horizontal coupling of inversion heights that allows for the coexistence of closed-cell and open-cell clouds within a region of hundreds of kilometers (Berner et al., 2011). Kazil et al. (2011) implemented a more sophisticated model of the sulfur cycle and aerosol processing within an LES and was able to reproduce the observed structure of the aerosol-depleted "ultraclean layer" (as detailed in observations by Wood et al., 2011a) and its potential for supporting spontaneous nucleation of ultrafine aerosol. More recently, Berner et al. (2013) showed that a large-domain cloud-resolving simulation with interactive aerosols can develop long-lived, mutually supporting regions of open and closed cells existing side by side, suggesting that, under some large-scale meteorological and aerosol conditions, the POCovercast system is a self-maintaining form of mesoscale cloud organization. POC modeling studies have been initialized based on one DYCOMS-II case (Wang and Feingold, 2009a, b) and one VOCALS case (RF06) (Wang et al., 2010; Berner et al., 2011; Kazil et al., 2011). The boundary layer heights of the two cases range from $800 \mathrm{~m}$ (Van Zanten and Stevens, 2005) to $1600 \mathrm{~m}$ (Wood et al., 2011a), suggesting diverse environments in which POCs exist. More observational analyses of POCs are therefore necessary to identify the boundary layer properties that are common across different POC cases and those properties that are more variable.

Early observations of POCs were fortuitous because their formation cannot be easily forecast and because they form over remote oceans. The VAMOS Ocean Cloud Atmosphere Land Study Regional Experiment (VOCALS-REx), conducted over the southeast Pacific Ocean during October and November of 2008, was the first concerted field campaign for which POCs developing in a larger region were systematically targeted for observational sampling (Wood et al., 2011b; Mechoso et al., 2014). Wood et al. (2011a) provides a detailed analysis of one VOCALS case (RF06) using data from two aircraft. Cui et al. (2014) describe measurements from another VOCALS POC case sampled by the UK BAe146 aircraft before the NSF/NCAR C-130 sampled it during RF13. The current study investigates the commonalities and variations across five different VOCALS POC cases, including RF06 and RF13. We assess our current conceptual model of POC structure and the conditions necessary to form and maintain them. Section 2 gives an overview of the measurements available from the C-130 and describes how POCs are differentiated from the surrounding overcast region using satellite infrared imagery. The following five sections present our results, including the large-scale context in which the POCs were observed (Sect. 3) and comparisons of their boundary layer (Sect. 4), cloud and precipitation (Sect. 5), 
and aerosol (Sect. 6) characteristics with the surrounding overcast regions and two POC-like cases (Sect. 7). A discussion and a summary of the results are given in Sect. 8.

\section{Data and methods}

\subsection{Data}

During VOCALS-REx, six research flights flown by the NSF/NCAR C-130 sampled the atmospheric conditions across transitions from closed to open cellular clouds accompanied by clear corresponding changes in cloud microphysics (Wood et al., 2011b). Five of those six research flights are used in this analysis, because the diurnal break-up of the closed-cell stratocumulus made it difficult to distinguish the closed-cell from the open-cell regions during RF14 (15 November). The five remaining research flights examined here are RF06 (28 October), RF07 (31 October), RF08 (2 November), RF09 (4 November), and RF13 (13 November). During VOCALS-REx, if a suspected POC was present within aircraft range when flight plans were made for a given day, the $\mathrm{C}-130$ was directed to sample the POC. The flight strategy consists of sawtooth profile legs from above the inversion to below cloud base, profile legs through the depth of the atmospheric boundary layer, and level flight legs flown $\sim 150 \mathrm{~m}$ above the surface in the subcloud layer, at cloud base $(\sim 700 \mathrm{~m})$, at cloud level $(\sim 1000 \mathrm{~m})$, and above cloud $(\sim 1500 \mathrm{~m})$. Level flight legs ranged in length from 120 to $240 \mathrm{~km}$. Figure 1 shows a typical flight strategy of POC sampling, followed by most flights, except for RF06 and RF13, in which an additional subcloud and cloud-level flight leg was flown.

For all flight legs, a suite of instruments measured thermodynamic quantities (temperature, water mixing ratio, pressure, etc., described in Wood et al., 2011b) to help characterize the structure of the boundary layer and lower free troposphere. Because the humidity measurements were found to be biased high in previous analyses (Bretherton et al., 2010), the humidity measurements from the Lyman-alpha hygrometer are corrected according to Bretherton et al. (2010). The Wyoming Cloud Radar (WCR), also aboard the C-130, provided radar reflectivity from cloud and precipitation hydrometeors above and below the aircraft. The column-maximum reflectivity from the WCR is used to estimate precipitation rates at cloud base inside and outside the POCs using the $Z-R$ relationship from Comstock et al. (2004). From the subcloud flight legs, the cloud fraction, cloud-base height, and cloud liquid water path are estimated using the upwardpointing Wyoming Cloud Lidar (WCL) and a G-band vapor radiometer (GVR) (Zuidema et al., 2012), respectively. Sea surface temperatures (SSTs) are remotely sensed by downward-viewing Heimann radiometric sensors and corrected by $1 \mathrm{~K}$ to correct a warm bias found by Bretherton et al. (2010).
Concentrations of aerosols of size $>0.1 \mu \mathrm{m}$ in clear air are obtained from the passive cavity aerosol spectrometer probe (PCASP) which measures the size distribution of aerosols with diameter between 0.1 and $3 \mu \mathrm{m}$. This size range encompasses most of the accumulation-mode aerosols and is representative of concentrations of cloud condensation nuclei $(\mathrm{CCN})$ at supersaturations typical of those in marine stratocumulus (Martin et al., 1994; Terai et al., 2012). Total aerosol concentrations $(\mathrm{CN})$ for particle diameters $>10 \mathrm{~nm}$ were obtained by the $3010 \mathrm{CN}$ counter (Clarke et al., 2007). Aerosol data are all filtered for possible splashing and shattering events from drizzle drops by removing aerosol data if any of the following conditions are met: liquid water content $>0.04 \mathrm{~g} \mathrm{~m}^{-3}$ (as measured by the Gerber PV-100 probe); drizzle drop concentration $>1 \mathrm{~L}^{-1}$ (as measured by the 2DC probe); or a $10 \mathrm{~s}$ forward-lagged, $11 \mathrm{~s}$ moving-window-mean drizzle water content $>10^{-4} \mathrm{~g} \mathrm{~m}^{-3}$ (as measured by the 2DC probe).

Measurements of cloud droplet concentrations $\left(N_{\mathrm{d}}\right)$ and mixing ratios $\left(q_{\mathrm{c}}\right)$ are obtained from a cloud droplet probe (CDP), which measures drops with radii between 1 and $23.5 \mu \mathrm{m}$. Similarly, measurements of drizzle drop concentrations $\left(N_{\mathrm{D}}\right)$ and mixing ratios $\left(q_{\mathrm{D}}\right)$ are obtained from a $2 \mathrm{DC}$ optical array probe for drops with radii larger than $30 \mu \mathrm{m}$ (Wood et al., 2011b). Unless otherwise stated, all measurements are analyzed at $1 \mathrm{~Hz}$ time resolution, corresponding to a spatial resolution of $\sim 100 \mathrm{~m}$. Cloudy air is distinguished from clear air in the cloud-level flight legs when the liquid water mixing ratio from either the Gerber PV-100 probe or the CDP+2DC exceeded $0.03 \mathrm{~g} \mathrm{~kg}^{-1}$.

In order to locate the POC boundaries regardless of the time of day, infrared brightness temperature imagery from channel 4 (centered on $11 \mu \mathrm{m}$ ) of the Geostationary Operational Environmental Satellite imager (GOES-10), obtained roughly every $15 \mathrm{~min}$, is used to locate the flight legs in relation to the POC boundary.

\subsection{Differentiating between POC and overcast regions}

We divide each relevant flight leg into POC, transition, and overcast (OVC) subsections by visual inspection of the GOES-10 infrared (IR) imagery. This allows us to compare the various boundary layer properties in the POC with those in the overcast region. This approach is similar but not identical to Wood et al. (2011a) and Berner et al. (2011), who instead used radar reflectivity to distinguish the regions. Figure 2 shows subcloud flight legs from each of the five POC cases overlaid on GOES-10 IR images taken closest to the leg time. The transition region is identified to ensure that POC and overcast sections of the flight leg solely sampled the corresponding cloud types, with its width determined from the sharpness in the transition from overcast to broken clouds along the leg. In the following analysis, we compare the thermodynamic, macrophysical, and microphysical characteristics in the POC region and the overcast region. 


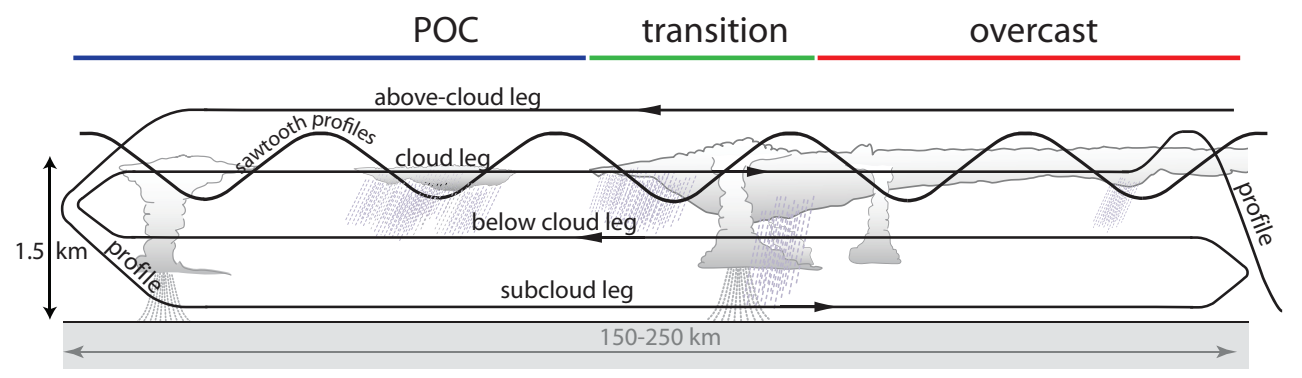

Figure 1. Typical flight strategy taken by the NSF/NCAR C-130 during POC sampling (adapted from Fig. 7 of Wood et al., 2011 a).

\section{Large-scale context}

\subsection{Geographical and diurnal context}

Four of the POC flights in this study were located at $80^{\circ} \mathrm{W}$ and just to the north and south of $20^{\circ} \mathrm{S}$. The RF13 POC was located slightly to the east at $78^{\circ} \mathrm{W}$ (see Table 1 and Fig. 2). The region around $20^{\circ} \mathrm{S}$ and $80^{\circ} \mathrm{W}$ has been characterized by a combination of aircraft and shipboard measurements made during VOCALS-REx (Bretherton et al., 2010; Allen et al., 2011) and shipboard measurements from seven research cruises conducted from 2001 to 2008 (de Szoeke et al., 2012), for which the values are summarized in Tables 2-4. During October and November, the region was characterized by a median inversion height of $\sim 1240 \mathrm{~m}$ (25th-75th percentile range of 1220-1330 m; Bretherton et al., 2010), a diurnal-mean cloud thickness of $250 \mathrm{~m}$, corresponding to a mean liquid water path of $81 \mathrm{~g} \mathrm{~m}^{-2}$ (de Szoeke et al., 2012), and a mean cloud fraction of $90 \%$ (de Szoeke et al., 2012). Surface mixed-layer accumulation-mode aerosol concentrations in the region average approximately $140 \mathrm{~cm}^{-3}$, but with large variations such that the 25 th-75th percentile range is $70-220 \mathrm{~cm}^{-3}$ (Allen et al., 2011). Because stratocumulus cloud cover and drizzle rates tend to maximize in the early morning hours (Wood et al., 2008; Leon et al., 2008; de Szoeke et al., 2012), and because a goal of VOCALS-REx was to observe the precipitation characteristics in POCs, four of the five POC-sampling research flights were conducted in the early morning hours (Table 1). Large differences in cloud properties between the one POC sampled during midday (RF13) and the four POCs sampled during early morning are apparent in the precipitation rate and in-cloud turbulence (Table 3 and Sect. 5.3).

\subsection{Synoptic setting}

The C-130 VOCALS sampling period of 15 October to 15 November 2008 was characterized as a quiescent period, in which little synoptic activity propagated from the midlatitudes into the VOCALS region (Toniazzo et al., 2011). During this quiescent period, however, POCs contributed substantially to cloud cover variability (Toniazzo et al., 2011). Although no evidence has been found to show that the syn-
Table 1. Time and location of POC flights. The local standard time is UTC $-5.3 \mathrm{~h}$ at $80^{\circ} \mathrm{W}$. Location denotes the center of all flight legs flown for POC sampling.

\begin{tabular}{llll}
\hline Flight & Date & $\begin{array}{l}\text { Time sampled } \\
\text { - UTC }\end{array}$ & $\begin{array}{l}\text { Location } \\
\text { sampled }\end{array}$ \\
\hline RF06 & 28 Oct 2008 & $08: 24-13: 23$ & $18^{\circ} \mathrm{S}, 80^{\circ} \mathrm{W}$ \\
RF07 & 31 Oct 2008 & $08: 32-11: 37$ & $22.5^{\circ} \mathrm{S}, 80^{\circ} \mathrm{W}$ \\
RF08 & 2 Nov 2008 & $09: 07-12: 24$ & $22.5^{\circ} \mathrm{S}, 80^{\circ} \mathrm{W}$ \\
RF09 & 4 Nov 2008 & $08: 39-11: 32$ & $22^{\circ} \mathrm{S}, 80^{\circ} \mathrm{W}$ \\
RF13 & 13 Nov 2008 & $16: 03-20: 11$ & $19.5^{\circ} \mathrm{S}, 78^{\circ} \mathrm{W}$ \\
\hline
\end{tabular}

optic waves directly cause the POC features to form or that they help maintain POC features, because midlatitude storms have the potential of affecting air masses advecting into VOCALS region (George and Wood, 2010), we cannot discount a possible influence from midlatitude synoptic activity on the formation of POCs.

\subsection{Free troposphere}

Lower tropospheric stability (LTS) over the subtropical stratocumulus regions is positively correlated with low cloud cover (Klein and Hartmann, 1993; Leon et al., 2008). In Table 2, we compare the LTS, calculated as the potential temperature difference between the $700 \mathrm{hPa}$ level and the surface, over the POCs and surrounding overcast region. We find no indication that the VOCALS POCs formed under remarkably high or low LTS conditions. Because the aircraft did not fly many profiles up to $700 \mathrm{hPa}(\sim 3100 \mathrm{~m})$, the same $700 \mathrm{hPa}$ potential temperatures are used to calculate LTS in POCs and overcast regions in Table 2. The surface potential temperatures are the mean potential temperature from the subcloud legs in each region. Because surface potential temperatures did not vary by much between separate POC cases (287-289 K), variations in LTS between cases are largely due to differences in the $700 \mathrm{hPa}$ temperatures.

Stevens et al. (2005) observed a moister free troposphere (FT) above a northeast Pacific POC, which led to the hypothesis that POCs formed under regions with moister FT. Wood et al. (2008), however, found no evidence in the southeast 

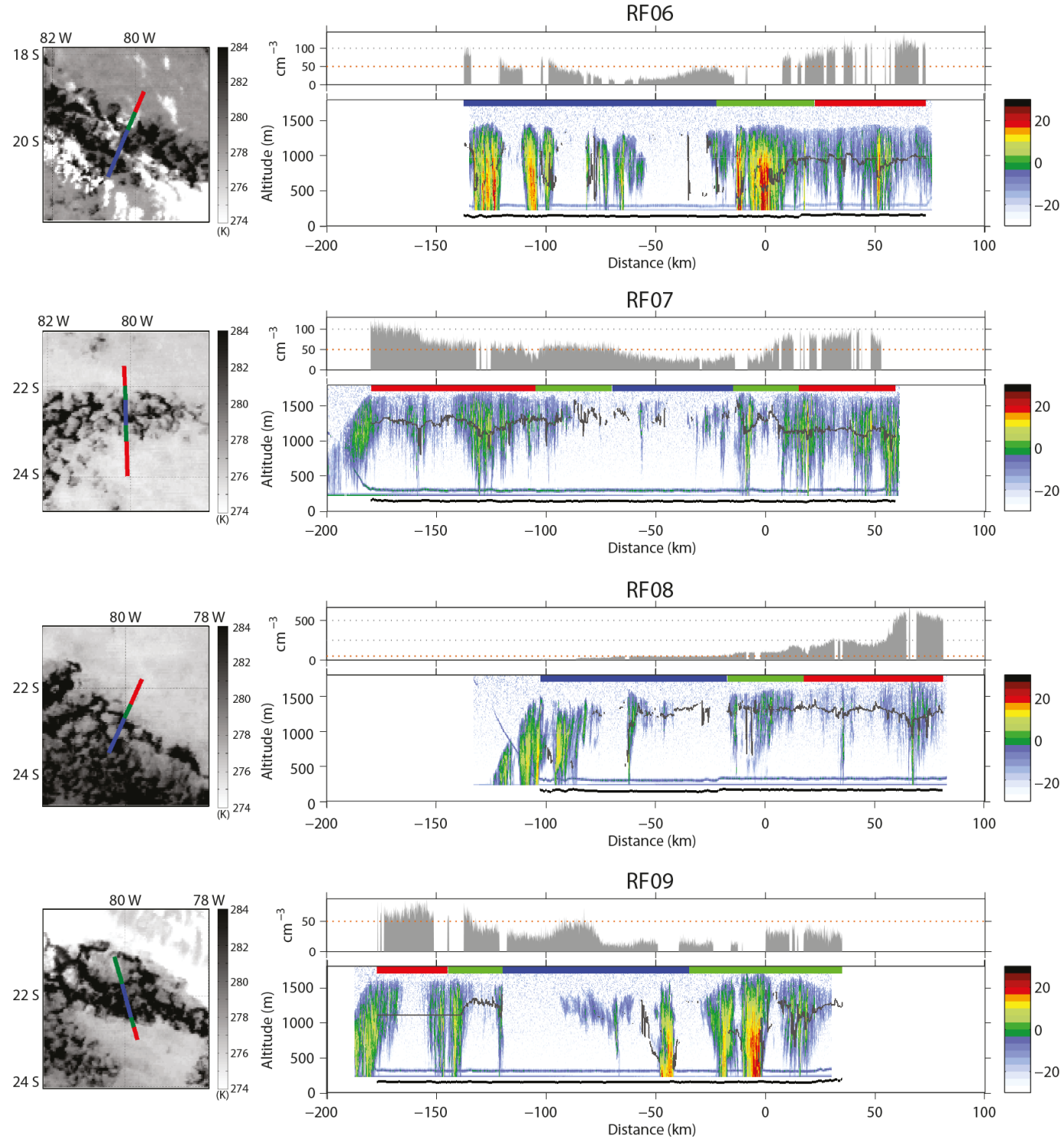

RF13

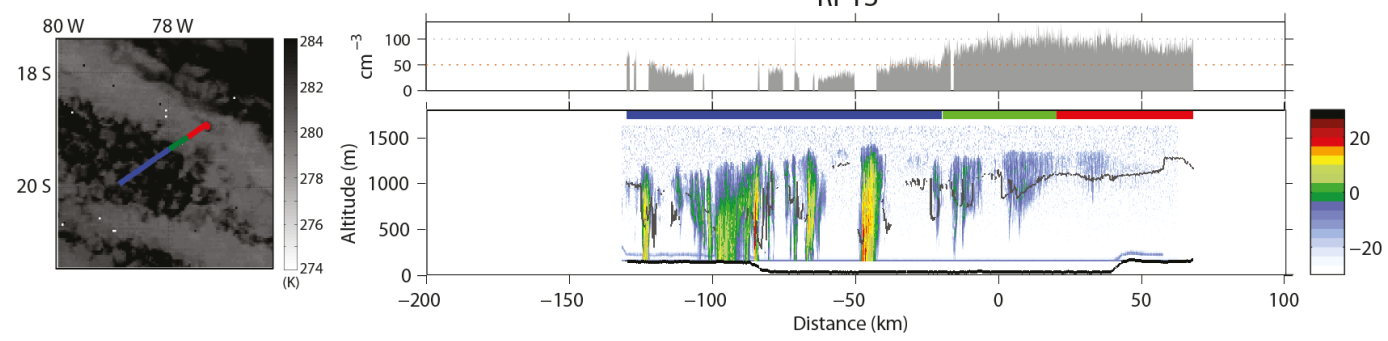

Figure 2. C-130 flight tracks overlaid on GOES-10 satellite imagery, in situ PCASP concentrations, and Wyoming Cloud Radar (WCR) reflectivity cross sections from subcloud legs of the five POC cases analyzed in this study. For each POC case, the left panel shows the location of the flight legs in relation to the overall POC structure. The flight track is colored with regard to distinction between POC (blue), overcast (red), and transition (green). The top panel for each case shows the aerosol concentration as measured by the PCASP $(0.1 \mu \mathrm{m}<D<3 \mu \mathrm{m})$, where concentrations are filtered for drizzle events. The dotted line indicating $50 \mathrm{~cm}^{-3}$ is highlighted in orange to remind the reader of the changing scale along the ordinate. The panel below the PCASP concentrations shows the WCR column reflectivities (dBZ) with the cloudbase height from Wyoming Cloud Lidar traced in gray. All radar cross sections and aerosol concentration time series are aligned along the middle of the north transition region. 
Table 2. Boundary layer and free-tropospheric conditions in the POC and overcast (OVC) regions of the five observed POC cases. In addition to the five VOCALS cases examined in this study, the mean conditions at $80^{\circ} \mathrm{W}$ during the VOCALS field campaign and measurements reported in previous studies are listed for comparison. Mean and standard deviations are recorded as $\mu \pm \sigma$, whereas 25 th-75th percentile ranges are shown as a range $x_{25 \text { th }}-x_{75 \text { th }}$. For conditions that vary with height level, the variables are preceded by SC (subcloud), CL (cloud), and AC (above cloud) to indicate the height level at which the measurements were taken. The inversion base height $\left(z_{i}\right.$, base $)$ is estimated from the profile legs as the height of the coldest temperature in the lower troposphere. The inversion height $\left(z_{\mathrm{i}}\right)$ is estimated from the profile legs as the height of the maximum of the $5 \mathrm{~s}$ running mean of $\mathrm{d} \theta / \mathrm{d} z$. The lower-tropospheric stability (LTS), defined as the potential temperature difference between $700 \mathrm{hPa}$ and the surface, was calculated from taking the difference between the mean SC leg potential temperature and the mean potential temperatures calculated by the C-130 between 699 and $701 \mathrm{hPa}$ and within $\pm 2.5^{\circ}$ latitude and longitude of the POC location in Table 1.

\begin{tabular}{|c|c|c|c|c|c|c|c|c|}
\hline Case & Region & $\begin{array}{r}z_{\mathrm{i}, \text { base }} \\
(\mathrm{m})\end{array}$ & $\begin{array}{r}z_{\mathrm{i}} \\
(\mathrm{m})\end{array}$ & $\begin{array}{r}\text { LTS } \\
(\mathrm{K})\end{array}$ & $\begin{array}{r}\mathrm{AC} q_{\mathrm{v}} \\
\left(\mathrm{g} \mathrm{kg}^{-1}\right)\end{array}$ & $\begin{array}{l}\mathrm{SST} \\
\left({ }^{\circ} \mathrm{C}\right)\end{array}$ & $\begin{array}{r}T_{0}-\mathrm{SST} \\
(\mathrm{K})\end{array}$ & $\begin{array}{r}\mathrm{SC} U \\
\left(\mathrm{~m} \mathrm{~s}^{-1}\right)\end{array}$ \\
\hline \multirow[t]{2}{*}{ RF06 } & POC & $1262 \pm 74$ & $1411 \pm 22$ & 27 & $0.53 \pm 0.21$ & 17.3 & -1.0 & $11.3 \pm 0.9$ \\
\hline & OVC & $1338 \pm 49$ & $1393 \pm 18$ & 26 & $0.21 \pm 0.03$ & 17.7 & -0.5 & $11.1 \pm 0.9$ \\
\hline \multirow[t]{2}{*}{ RF07 } & POC & $1587 \pm 15$ & $1658 \pm 25$ & 22 & $0.27 \pm 0.03$ & 17.3 & -1.6 & $8.0 \pm 1.4$ \\
\hline & OVC & $1613 \pm 41$ & $1654 \pm 23$ & 21 & $0.23 \pm 0.07$ & 17.7 & -1.0 & $9.7 \pm 1.1$ \\
\hline \multirow[t]{2}{*}{ RF08 } & POC & $1599 \pm 92$ & $1642 \pm 113$ & 23 & $0.31 \pm 0.05$ & 17.5 & -0.6 & $7.7 \pm 1.1$ \\
\hline & OVC & $1656 \pm 34$ & $1672 \pm 24$ & 23 & $0.24 \pm 0.06$ & 17.6 & -0.0 & $8.2 \pm 0.7$ \\
\hline \multirow[t]{2}{*}{ RF09 } & POC & $1420 \pm 58$ & $1543 \pm 129$ & 24 & $0.26 \pm 0.12$ & 17.5 & -1.5 & $7.2 \pm 1.1$ \\
\hline & OVC & $1521 \pm 107$ & $1539 \pm 101$ & 23 & $0.68 \pm 0.10$ & 17.8 & -0.8 & $5.7 \pm 0.7$ \\
\hline \multirow[t]{2}{*}{ RF13 } & POC & $1343 \pm 31$ & $1365 \pm 16$ & 30 & $0.78 \pm 0.12$ & 17.9 & -1.7 & $4.9 \pm 1.2$ \\
\hline & OVC & $1298 \pm 15$ & $1307 \pm 19$ & 29 & $0.33 \pm 0.09$ & 17.5 & -0.3 & $5.0 \pm 1.2$ \\
\hline \multicolumn{9}{|l|}{ Mean } \\
\hline $20^{\circ} \mathrm{S}, 80^{\circ} \mathrm{W}$ & & $1220-1330^{\mathrm{a}}$ & & $24.7 \pm 2.4^{b}$ & & $17.8 \pm 0.4^{\mathrm{a}}$ & & $8.0 \pm 1.9^{b}$ \\
\hline \multicolumn{9}{|l|}{ DYCOMS II } \\
\hline \multirow[t]{2}{*}{$\mathrm{VS}^{2} 5^{\mathrm{c}}$} & POC & 794 & & & & & & \\
\hline & OVC & 794 & & & & & & \\
\hline P06 ${ }^{\mathrm{d}}$ & POC & 794 & & & & & & \\
\hline \multicolumn{9}{|l|}{ DECS } \\
\hline \multirow[t]{2}{*}{$\mathrm{S} 06^{\mathrm{e}}$} & POC & $740-800$ & & & & & & \\
\hline & OVC & $710 \pm 75$ & & & & & & \\
\hline
\end{tabular}

Pacific that POCs formed preferentially in regions with a moister FT. Likewise, if we compare the water vapor mixing ratio $\left(q_{\mathrm{v}}\right)$ from the above-cloud flight legs flown over the POC and overcast region, then we find that $q_{\mathrm{v}}$ is not consistently higher above the VOCALS POCs (Table 2).

\section{Boundary layer structure}

\subsection{Air-sea temperature difference}

Air-sea temperature differences and wind speeds determine the temperature flux at the surface. Except for RF13, the SSTs are slightly lower in the POC than in the overcast region
(Table 2). However, the apparent SST decrease in the POC is likely a sampling artifact. First, the approximately $1 \mathrm{~K}$ decrease in the subcloud temperature and $1 \mathrm{~g} \mathrm{~kg}^{-1}$ increase in the water vapor mixing ratio in the POC can lead to a low bias in the SST retrieved over the POC. Second, the decrease in cloud cover in the POC can decrease the amount of reflected infrared radiation, also leading to a low bias in SST retrieved over the POC (Smith et al., 1996). Indeed, when the retrieved SST and downward infrared irradiance are compared within the POC segments of the flight legs, they somewhat correlate with each other. Despite this potential low bias of the POC SSTs, the estimated air-sea temperature difference inside the POC is larger than in the overcast region (Table 2). 
Table 3. Similar to Table 2 but for boundary layer thermodynamic and cloud macrophysical properties. The lifting condensation levels (LCL) from the SC legs are reported here. Cloud fraction (CF) is based on the WCL cloud detection from the subcloud legs. The decoupling parameter $\Delta z$ is the mean height difference between the cloud-base height and the LCL.

\begin{tabular}{|c|c|c|c|c|c|c|c|}
\hline Case & Region & $\begin{array}{r}\Delta z \\
(\mathrm{~m})\end{array}$ & $\begin{array}{r}\mathrm{LCL} \\
(\mathrm{m})\end{array}$ & $\begin{array}{l}\mathrm{CL} \overline{w^{\prime 2}} \\
\left(\mathrm{~m}^{2} \mathrm{~s}^{-2}\right)\end{array}$ & $\begin{array}{l}\mathrm{CF} \\
(\%)\end{array}$ & $\begin{array}{c}\text { SC LWP } \\
\left(\mathrm{g} \mathrm{m}^{-2}\right)\end{array}$ & $\begin{array}{r}Z_{\max } R \\
\left(\mathrm{~mm} \mathrm{~d}^{-1}\right)\end{array}$ \\
\hline \multirow[t]{2}{*}{ RF06 } & POC & 343 & 480 & 0.17 & 56 & $251 \pm 238$ & 4.3 \\
\hline & OVC & 89 & 829 & 0.69 & 100 & $173 \pm 86$ & 2.6 \\
\hline \multirow[t]{2}{*}{ RF07 } & $\mathrm{POC}$ & 781 & 605 & 0.05 & 75 & $27 \pm 25$ & 5.8 \\
\hline & OVC & 255 & 950 & 0.52 & 100 & $166 \pm 79$ & 2.1 \\
\hline \multirow[t]{2}{*}{ RF08 } & $\mathrm{POC}$ & 545 & 619 & 0.09 & 80 & $110 \pm 81$ & 5.0 \\
\hline & OVC & 299 & 968 & 0.67 & 100 & $131 \pm 107$ & 0.6 \\
\hline \multirow[t]{2}{*}{ RF09 } & POC & 429 & 532 & 0.08 & 73 & $107 \pm 194$ & 1.7 \\
\hline & OVC & - & 845 & 0.37 & - & $137 \pm 62$ & 1.3 \\
\hline \multirow[t]{2}{*}{ RF13 } & $\mathrm{POC}$ & 372 & 419 & 0.03 & 83 & $215 \pm 206$ & 2.8 \\
\hline & OVC & 517 & 569 & 0.12 & 100 & $59 \pm 39$ & 0.3 \\
\hline \multicolumn{8}{|l|}{ Mean } \\
\hline $20^{\circ} \mathrm{S}, 80^{\circ} \mathrm{W}$ & & $309 \pm 147^{\mathrm{a}}$ & $840 \pm 60^{\mathrm{b}}$ & $0.53 \pm 0.14^{\mathrm{a}}$ & $90 \pm 4^{\mathrm{b}}$ & $81 \pm 10^{\mathrm{b}}$ & $0.3-2.3^{\mathrm{a}}$ \\
\hline \multicolumn{8}{|l|}{ DYCOMS II } \\
\hline \multirow[t]{2}{*}{$\mathrm{VSO}^{\mathrm{c}}$} & POC & & & $0.42 \pm 0.03$ & & & \\
\hline & OVC & & & $0.32 \pm 0.03$ & & & \\
\hline
\end{tabular}

${ }^{a}$ Estimated from flight-mean C-130 data taken between 77.5 and $82.5^{\circ} \mathrm{W}$ across 11 research flights.

b Inferred from de Szoeke et al. (2012).

c Van Zanten and Stevens (2005).

The cooler surface air temperatures in the POC, likely a result of cold pool formation, increase the air-sea temperature difference in the POC.

Relative changes in wind speed across the POC-overcast transition are small (Table 2). Therefore, any systematic changes in the surface sensible and latent heat fluxes are likely due to air-sea temperature and moisture differences in the POC. Across different POCs, a large range in surfacelevel horizontal wind speeds was measured (Table 2), which indicates that the maintenance of POCs does not require stronger or weaker winds.

\subsection{Inversion height and structure}

A critical parameter in marine boundary layer (MBL) evolution is the inversion height, which determines the cloud-top height and affects the likelihood of boundary layer decoupling (Jones et al., 2011). The inversion base height ( $z_{\mathrm{i}, \text { base }}$ ) is estimated from the profile legs as the height of the lowest temperature in the lower troposphere (Jones et al., 2011; Wood et al., 2011a). The $z_{\mathrm{i}}$, base of the observed POCs and the surrounding clouds ranges from 1250 to $1650 \mathrm{~m}$ (Table 2), which is on the higher end of the range of $z_{\mathrm{i}}$, base observed at $80^{\circ} \mathrm{W}$ during all the VOCALS-REx flights (Bretherton et al., 2010), but there is no indication that POCs only form in deeper boundary layers. If we compare the POC with the surrounding overcast region, the inversion base height is 25 to $100 \mathrm{~m}$ lower in the POC than in the overcast region in RF06, RF07, RF08, and RF09, but $50 \mathrm{~m}$ higher for RF13, the one POC sampled during the daytime. Inadequate sampling precludes attributing this difference to the diurnal cycle. The $z_{\mathrm{i}}$, base observed in the VOCALS POCs is substantially deeper than the 700-800 m inversion base heights of POCs observed previously over the northeast Pacific (see Table 2; Van Zanten and Stevens, 2005; Sharon et al., 2006). We conclude that POCs can be produced in boundary layers with a range of inversion heights.

The strength of the inversion determines how easily freetropospheric air can be entrained into the MBL. We compare the inversion structure over the POC and overcast region in Fig. 3. A mean profile for the overcast and POC region is constructed for each case from averaging the potential temperature from the profiles in $25 \mathrm{~m}$ height bins. To compare results from different $\mathrm{POC}$ cases, the mean inversion height $\left(z_{\mathrm{i}}\right)$ from each POC and overcast case found in Table 2 is subtracted from each profile. Rather than using $z_{\mathrm{i} \text {, base for }}$ this purpose (which would align the bottom of the gradient regions in the profiles), we define the $z_{\mathrm{i}}$ in each flight profile to correspond to the maximum of the $5 \mathrm{~s}$ running mean of $\mathrm{d} \theta / \mathrm{d} z$ and subtract the mean of those heights from each 
Table 4. Similar to Table 2 but for cloud microphysical and aerosol properties. Aerosol concentrations are filtered for possible drizzle shattering events.

\begin{tabular}{|c|c|c|c|c|c|c|c|c|}
\hline Case & Region & $\begin{array}{r}N_{\mathrm{d}} \\
\left(\mathrm{cm}^{-3}\right)\end{array}$ & $\begin{array}{r}\mathrm{CL} q_{\mathrm{c}} \\
\left(\mathrm{g} \mathrm{kg}^{-1}\right)\end{array}$ & $\begin{array}{r}\mathrm{CL} q_{\mathrm{D}} \\
\left(\mathrm{g} \mathrm{kg}^{-1}\right)\end{array}$ & $\begin{array}{c}\mathrm{SC} N_{\mathrm{a}} \\
\left(\mathrm{cm}^{-3}\right)\end{array}$ & $\begin{array}{l}\mathrm{CL} \mathrm{N} N_{\mathrm{a}} \\
\left(\mathrm{cm}^{-3}\right)\end{array}$ & $\begin{array}{l}\mathrm{SC} \mathrm{CN} \\
\left(\mathrm{cm}^{-3}\right)\end{array}$ & $\begin{array}{l}\text { CL CN } \\
\left(\mathrm{cm}^{-3}\right)\end{array}$ \\
\hline \multirow[t]{2}{*}{ RF06 } & POC & $10 \pm 13$ & 0.06 & 0.11 & $32 \pm 18$ & $1.7 \pm 4.7$ & 137 & 80 \\
\hline & OVC & $94 \pm 21$ & 0.31 & 0.03 & $103 \pm 25$ & - & 145 & - \\
\hline \multirow[t]{2}{*}{ RF07 } & $\mathrm{POC}$ & $4 \pm 3$ & 0.03 & 0.08 & $29 \pm 9$ & $1.1 \pm 1.8$ & 140 & 80 \\
\hline & OVC & $67 \pm 29$ & 0.34 & 0.04 & $74 \pm 20$ & - & 195 & - \\
\hline \multirow[t]{2}{*}{ RF08 } & POC & $13 \pm 12$ & 0.06 & 0.09 & $40 \pm 13$ & $22.0 \pm 11.4$ & 383 & 261 \\
\hline & OVC & $208 \pm 75$ & 0.27 & 0.00 & $324 \pm 166$ & - & 636 & - \\
\hline \multirow[t]{2}{*}{ RF09 } & POC & $6 \pm 11$ & 0.02 & 0.05 & $24 \pm 12$ & $6.1 \pm 12.2$ & 307 & 214 \\
\hline & OVC & $52 \pm 20$ & 0.14 & 0.02 & $65 \pm 9$ & - & 207 & - \\
\hline \multirow[t]{2}{*}{ RF13 } & POC & $8 \pm 8$ & 0.04 & 0.06 & $37 \pm 11$ & $4.2 \pm 3.9$ & 177 & 316 \\
\hline & OVC & $94 \pm 62$ & 0.26 & 0.02 & $90 \pm 13$ & - & 247 & - \\
\hline \multicolumn{9}{|l|}{ Mean } \\
\hline $20^{\circ} \mathrm{S}, 80^{\circ} \mathrm{W}$ & & $133 \pm 57^{\mathrm{a}}$ & $0.09-0.29^{\mathrm{a}}$ & $0.00-0.04^{\mathrm{a}}$ & $70-220^{\mathrm{b}}$ & - & $300-480^{\mathrm{b}}$ & - \\
\hline \multicolumn{9}{|l|}{ DYCOMS II } \\
\hline \multirow{2}{*}{$\mathrm{VSO}^{\mathrm{c}}$} & $\mathrm{POC}$ & $55 \pm 16$ & & & & & & \\
\hline & OVC & $70 \pm 17$ & & & & & & \\
\hline $\mathrm{P} 6^{\mathrm{d}}$ & POC & $30 \pm 15$ & & & 40 & & & \\
\hline \multicolumn{9}{|l|}{ DECS } \\
\hline \multirow[t]{2}{*}{$\mathrm{S}^{\mathrm{e}} \mathrm{e}^{\mathrm{e}}$} & POC & 20 & & & $\sim 10$ & & & \\
\hline & OVC & $40-60$ & & & $\sim 50$ & & & \\
\hline \multirow[t]{2}{*}{$\mathrm{W} 08^{\mathrm{f}}$} & POC & & & & $\sim 20-50$ & & & \\
\hline & OVC & & & & $\sim 100-300$ & & & \\
\hline
\end{tabular}

averaged profile. Table 2 gives this mean $z_{\mathrm{i}}$ for the POC and overcast (OVC) regions of each flight; for the four nocturnal flights, the mean $z_{\mathrm{i}}$ is quite similar in the POC and OVC regions, even though $z_{\mathrm{i}}$, base is lower in the POC. Figure 3 shows that the inversion is typically sharper in the OVC region than in the POC. This is expected given how radiative cooling from thick overcast clouds helps to sharpen the inversion. However, the inversion structure also differs from case to case. For example, the inversion in the overcast profile from RF09 is especially hard to identify. This is partly a result of averaging four different overcast profiles into one, but visual inspection shows that the inversions in individual profiles from the overcast region of RF09 are also less sharp than in other cases.

\subsection{Decoupling}

The degree to which the boundary layer is decoupled can be quantified by taking the difference $(\Delta z)$ between the cloudbase height and the lifting condensation level (LCL) from the subcloud flight legs (Jones et al., 2011). Defined this way, the decoupling gives an indication of the relative timescales between boundary layer mixing and processes that act to stabilize the boundary layer. From Table 3, we see for all cases that the POC has a significantly $(150-350 \mathrm{~m})$ lower LCL. In the nocturnal cases, the $\Delta z$ is larger (indicating stronger decoupling) in the POC than the surrounding OVC region. In the one daytime flight (RF13), the OVC is more decoupled, consistent with observational and LES studies that find that solar insolation strongly decouples the daytime overcast boundary layer (Turton and Nicholls, 1987; Bretherton et al., 2004; Caldwell and Bretherton, 2009). Although Wood et al. (2011a) noted that the OVC region surrounding the RF06 

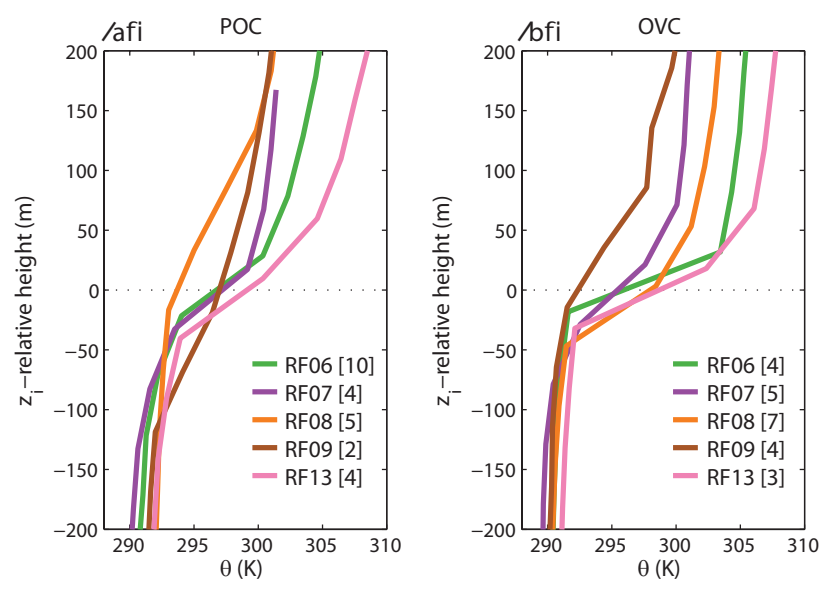

Figure 3. Potential temperature $(\theta)$ structure in POCs (left) and in overcast regions (right). Profiles are mean profiles based on data from profiles binned every $25 \mathrm{~m}$. The number of individual profiles that are used to calculate the mean profiles is indicated in brackets next to each flight number. The mean height of maximum potential temperature increase is subtracted from each profile to examine the structures relative to the inversion height. Instead of the inversion base height, the mean height of the maximum vertical gradient in potential temperature is chosen for the reference height so that the temperature changes in each area are better aligned.

POC was well mixed $(\Delta z=86 \mathrm{~m})$, we find that this feature is not shared across the other POC cases.

The stronger decoupling in POCs is likely a manifestation of strong drizzle evaporation in the subcloud layer that leads to the stabilization and decoupling of the lower boundary layer. This traps surface fluxes in the lower levels of the boundary layer and leads to lower LCL. LES studies have shown that the increased stability from subcloud drizzle evaporation enhances the transition from closed to open cellular convection (Savic-Jovcic and Stevens, 2008) and that cold pools help to organize cumulus cloud convection (Wang et al., 2010; Berner et al., 2011). It should, however, be noted that cold pools are not exclusive to POCs but are also observed under non-POC-forming overcast stratocumulus, and hence do not serve as a sufficient condition for POC formation (Terai and Wood, 2013).

\subsection{Vertical wind variance $\left(\overline{w^{\prime 2}}\right)$}

Counteracting the stabilization of the boundary layer, the radiative cooling at cloud top drives turbulence and enhances the mixing between the cloud layer and underlying surface mixed layer. The strength of the turbulence can be quantified by the vertical velocity variance $\left(\overline{w^{\prime 2}}\right)$ measured within cloud-layer legs. The cloud-layer leg $\overline{w^{\prime 2}}$ is calculated by taking the variance of the vertical velocity in each of the POC and overcast segments of the cloud-layer flight leg. Corroborating Wood et al. (2011a), we find that $\overline{w^{\prime 2}}$ is lower in the POC across all cases (Table 3 ). The very low $\overline{w^{\prime 2}}$ values in both POC and OVC regions in the RF13 case sampled during midday are probably due to absorption of solar radiation, which reduces the net cloud-layer radiative cooling that helps drive turbulence. It is illuminating to see local variations in $\overline{w^{\prime 2}}$ over the course of a flight leg, which we calculate based on a $21 \mathrm{~s}(\sim 2 \mathrm{~km})$ moving window, which acts as a crude high-pass filter to isolate turbulent motions from mesoscale fluctuations. In Fig. 4, measurements from the cloud-level flight leg of the RF08 POC are shown to illustrate the observed changes in cloud, drizzle, and vertical wind speed across the POC-to-OVC transition. Figure $4 \mathrm{~b}$ shows that $\overline{w^{\prime 2}}$ is intermittent in the POC. Long stretches of very low $\overline{w^{\prime 2}}$ are interrupted by short bursts of elevated $\overline{w^{\prime 2}}$, which are associated with cumulus clouds. Although there are fluctuations in $\overline{w^{\prime 2}}$ in the overcast region, the values are generally high. Cloud-level $\overline{w^{\prime 2}}$ also gives an indication of how much turbulence is available to entrain air from the FT. The much lower values of cloud-layer $\overline{w^{\prime 2}}$ within POC regions compared to surrounding overcast regions with similar inversion temperature jumps suggest that the entrainment rates over the POCs are much smaller than in the surrounding overcast regions, as found with LES (Berner et al., 2011).

\section{Clouds and precipitation}

\subsection{Cloud macrophysics}

A defining difference between the POC and overcast regions in a satellite image is the difference in cloud fraction. For cloud fraction estimates we use the upward-pointing Wyoming Cloud Lidar to detect overlying cloud during the C-130 subcloud flight legs. Cloud fraction in overcast regions are nearly $100 \%$, while the POC regions have, on average, a more variable cloud fraction between 56 and $83 \%$ (Table 3). The all-sky mean LWP can be higher or lower in the POC than in the OVC region, but the relative standard deviation of LWP (the ratio of the standard deviation of LWP to its mean, both given in Table 3) tends to be larger in the POC. This, together with enhanced decoupling, is an indicator of more cumulus-like convection within the POC (Jones et al., 2011).

These differences in cloud structures also manifest themselves in the precipitation rates. The mean precipitation rates are higher in the POCs than in the surrounding OVC regions (Table 3). POC radar reflectivities are also more broadly distributed. The column-maximum radar reflectivity $\left(Z_{\max }\right)$ is plotted against the fraction of columns with reflectivity greater than the value in Fig. 5a. The broader distribution in the POC is evident from the shallower slope of the POC cumulative distribution compared to the OVC. In particular, there is a much larger fractional coverage of strong drizzle $>10 \mathrm{dBZ}$ for all POC cases. This contrast is consistent with statistics of the distribution of reflectivities within open- and closed-cell stratocumulus observed previously 

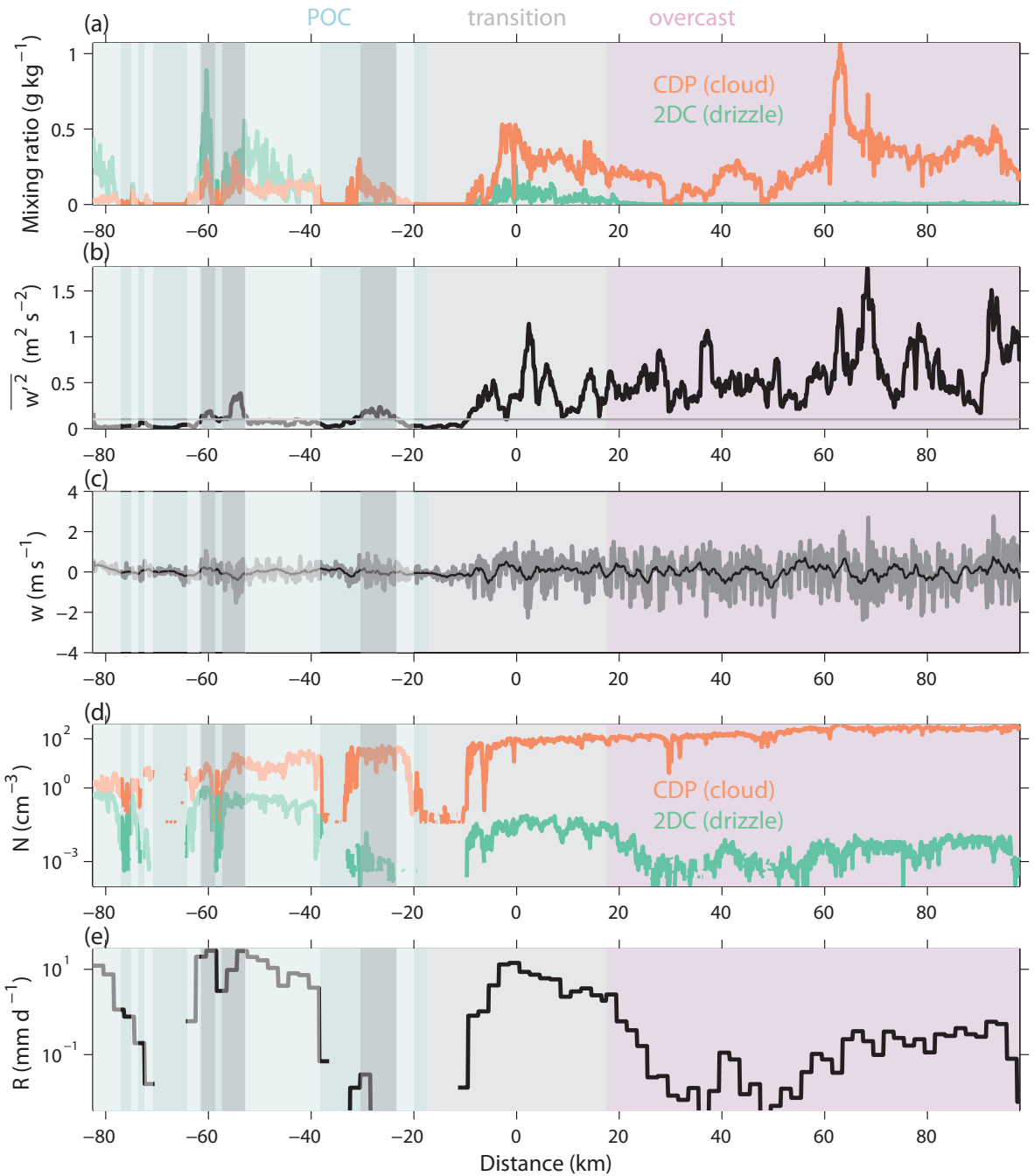

Figure 4. Cloud-level measurements from cloud-level flight leg showing (a) cloud $\left(q_{\mathrm{c}}-\right.$ orange $)$ and drizzle $\left(q_{\mathrm{D}}-\right.$ green) water mixing ratio; (b) $21 \mathrm{~s}$ running vertical wind variance $\left(\overline{w^{\prime 2}}\right)$; (c) $1 \mathrm{~Hz}$ vertical wind speed ( $w$ - gray) and $21 \mathrm{~s}$ mean $w$ (black); (d) cloud (orange - $\left.N_{\mathrm{d}}\right)$ and drizzle (green $-N_{\mathrm{D}}$ ) drop number concentration; and (e) precipitation rate $R$, based on $10 \mathrm{~s}$ averaged drizzle drop size distributions. In the POC segment of the flight leg, active clouds, defined as cloudy and drizzling data with $\overline{w^{\prime 2}} \geq 0.1 \mathrm{~m}^{2} \mathrm{~s}^{-2}$, are shaded in dark gray. Quiescent clouds, defined as cloudy and drizzling data with $\overline{w^{\prime 2}}<0.1 \mathrm{~m}^{2} \mathrm{~s}^{-2}$, are shaded in white. The clear regions in the POC, where liquid water mixing ratios measured by the CDP or by the Gerber PV-100 Probe did not exceed $0.03 \mathrm{~g} \mathrm{~kg}^{-1}$, are left unshaded.

over the southeast Pacific with shipboard cloud radar (Comstock et al., 2007) and over the global oceans with CloudSat (Muhlbauer et al., 2014).

Terai and Wood (2013) found that precipitation at lower elevations is a better indicator of cold pool formation than the occurrence of precipitation at cloud base (where the columnmaximum reflectivity is observed). Similarly, by examining the reflectivity at $250 \mathrm{~m}\left(Z_{250}\right)$ in Fig. 5b, instead of the column maximum $\left(Z_{\max }\right)$, we find that reflectivities greater than $0 \mathrm{dBZ}$ occur on average $10 \%$ of the time in POCs compared to only $\sim 1.5 \%$ of the time in the OVC region. Among the different precipitation characteristics, this best differentiates the POC precipitation from the OVC precipitation. The re- flectivities at $250 \mathrm{~m}$ are likely influenced by the amount of subcloud evaporation between the cloud base and $250 \mathrm{~m}$. Therefore, the higher occurrence of $>0 \mathrm{dBZ}$ precipitation at $250 \mathrm{~m}$ in the POC may reflect lower cloud-base heights in the POCs rather than a difference in the drizzle drop size distributions.

The macrophysical signatures of the cloud and precipitation properties in POCs all point to more cumuliform convection and correspondingly patchier and heavier precipitation within the POC than the surrounding overcast region. 


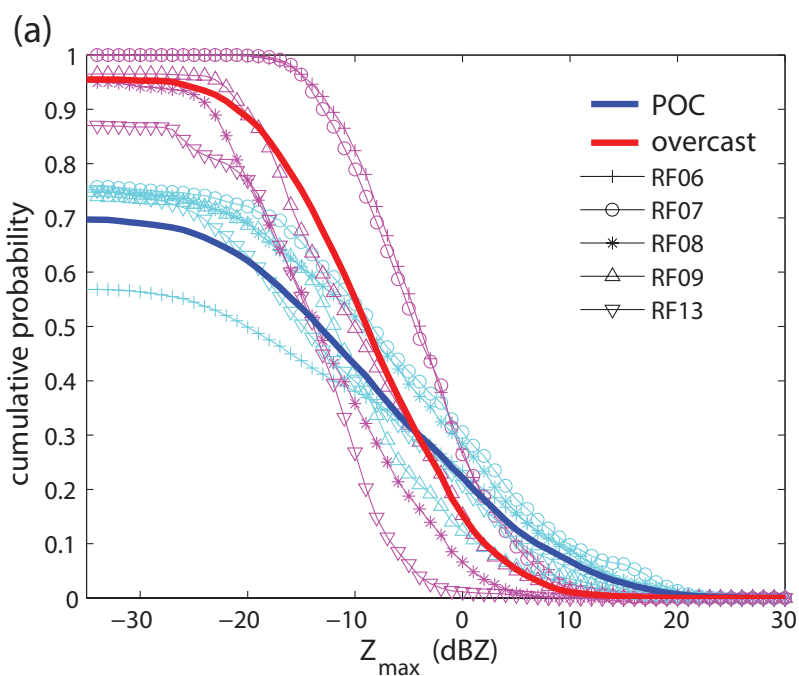

(b)

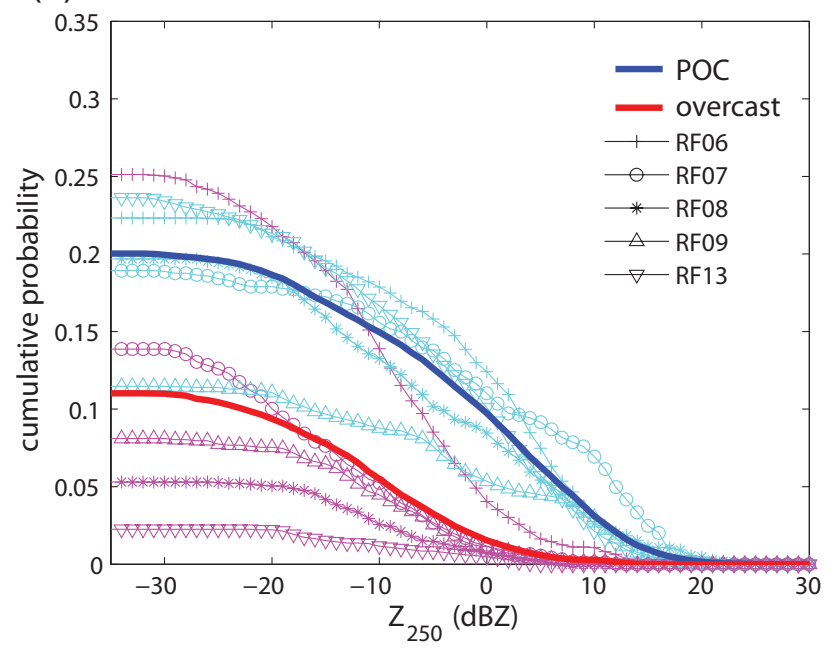

Figure 5. (a) The cumulative probability of column-maximum radar reflectivity $Z_{\max }$ greater than the abscissal value for overcast (red) and POC (blue) regions. The mean distribution are shown as bold lines, while individual flight legs are shown as thinner lines with markers. Radar reflectivities from all level flight legs are used to make the distribution. (b) Same as (a) but for radar reflectivity at $250 \mathrm{~m}$

\subsection{Cloud microphysics}

We now consider the cloud microphysical properties in the POCs. Consistent with previous POC observations (Petters et al., 2006; Sharon et al., 2006; Van Zanten and Stevens, 2005; Wood et al., 2011a), all five of the POC cases examined here show that cloud droplet number concentrations $\left(N_{\mathrm{d}}\right)$ decrease by more than a factor of 8 from the OVC region (Table 4). Whereas the mean cloud-layer $N_{\mathrm{d}}$ inside the POCs has a range between 4 and $13 \mathrm{~cm}^{-3}$ across cases, the $N_{\mathrm{d}}$ in the surrounding $\mathrm{OVC}$ region range from 52 to
$207 \mathrm{~cm}^{-3}$, further showing that POCs can persist when surrounded by a wide range of microphysical environments. In the surrounding $\mathrm{OVC}$, the case-to-case variations in $N_{\mathrm{d}}$ are highly correlated $(r=0.98)$ with the variations in subcloud PCASP aerosol concentrations $\left(N_{\mathrm{a}}\right)$. In the POCs, the relative changes in $N_{\mathrm{d}}$ are much more spatially variable than in OVC clouds, and $N_{\mathrm{d}}$ is at least a factor of 3 lower than the subcloud $N_{\mathrm{a}}$. As we discuss below (Sect. 5.3), this is due to dramatically lower $N_{\mathrm{d}}$ in "quiescent" stratocumulus clouds than in the "active" cumulus clouds that bring up the subcloud-layer aerosol. Despite this, the mean subcloud $N_{\mathrm{a}}$ is correlated with $N_{\mathrm{d}}$ in the POCs $(r=0.76)$.

The horizontal-mean cloud water mixing ratio $\left(q_{\mathrm{c}}\right)$ drops drastically inside the POCs (Table 4), due in part to a lower cloud fraction. In contrast, the horizontal-mean drizzle water mixing ratio $\left(q_{\mathrm{D}}\right)$ at least doubles inside the POCs, such that, in all five POC cases, the mass of water in the drizzle mode is larger than that in the cloud mode; remarkably, the $q_{\mathrm{D}} / q_{\mathrm{c}}$ ratio is at least 20-fold larger in the five POCs than in the OVC regions. The increase in the estimated precipitation rate from the surrounding $\mathrm{OVC}$ region to the $\mathrm{POC}$ is not as large as that in $q_{\mathrm{D}}$.

This apparent discrepancy is explained by the distinct size distribution of cloud and drizzle drops in the POC (Fig. 6). If we examine the cloud and drizzle drop size distributions measured by the CDP and 2DC in Fig. 6, we note a large increase in the drizzle drop concentrations in the POCs. Because the increase mainly occurs in the size range of smaller drops, the larger concentrations in the POC do not contribute to large differences in the precipitation rate. The increase in the number of large cloud and small drizzle drops is curious and may be related to the very low $N_{\mathrm{d}}$ and different cloud types in POCs.

\subsection{Active vs. quiescent clouds}

A closer examination of the clouds found in POCs reveals two general types of clouds: thinner, stratiform, quiescent clouds and cumulus-like active clouds (Wood et al., 2011a). We use a $\overline{w^{\prime 2}}$ threshold of $0.1 \mathrm{~m}^{2} \mathrm{~s}^{-2}$ as a means of distinguishing between the quiescent and active clouds inside the POC, except for the daytime case RF13, where the overall cloud-level vertical wind variance is low and hence where a threshold of $0.03 \mathrm{~m}^{2} \mathrm{~s}^{-2}$ is used. Here we calculate the $\overline{w^{\prime 2}}$ as the $21 \mathrm{~s}$ running mean $\overline{w^{\prime 2}}$. In the RF08 example (Fig. 4), one can see lower $N_{\mathrm{d}}$, lower vertical velocities, and consistently elevated drizzle drop number concentrations $\left(N_{\mathrm{D}}\right)$ in the quiescent clouds than in the active clouds. Table 5 quantifies and summarizes differences between the active and quiescent clouds in the POC regions, averaged for each of the five cases. Note that, unlike Table 4, all of the listed variables are only averaged over cloudy portions of the flight leg. Although there are uncertainties in taking area estimates from one or two cloud-level flight legs, we find that, across all POC cases, the quiescent clouds make up most of the 


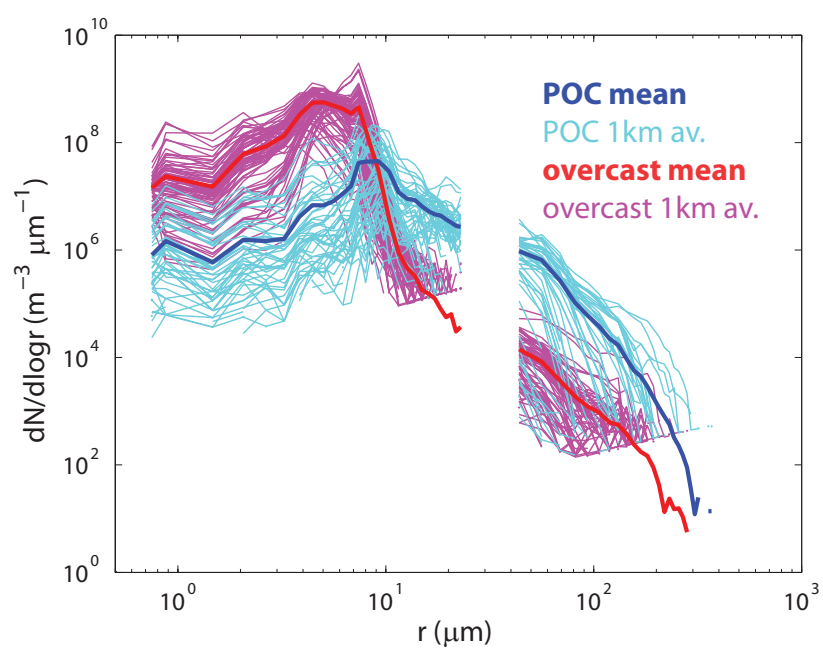

Figure 6. Droplet size distribution from the CDP and 2DC during a cloud-level flight leg from RF08. The cyan lines indicate distributions estimated from $1 \mathrm{~km}$ averages in the POC, while the thicker blue line indicates the mean of those distributions. The magenta lines indicate distributions estimated from $1 \mathrm{~km}$ averages in the overcast region, while the thicker red line indicates the mean of those distributions.

observed clouds in the POCs. The cloud droplet number concentration $N_{\mathrm{d}}$ is consistently lower within the quiescent clouds than in the active clouds, the latter having mean $N_{\mathrm{d}}$ on the order of $15 \mathrm{~cm}^{-3}$. RF07 is an apparent exception, but active clouds were rarely sampled on this flight, with only $2 \mathrm{~km}$ of the flight leg sampling active clouds. The ratio between $q_{\mathrm{c}}$ and $q_{\mathrm{D}}$ differs between the two regions, much like the change in ratio between overcast and POC clouds; in active clouds, $q_{\mathrm{c}}$ and $q_{\mathrm{D}}$ are comparable, whereas in quiescent clouds, $q_{\mathrm{D}}$ is far greater. Nonetheless, it is important to note that the $q_{\mathrm{D}}$ in both active and quiescent clouds of the POC is far greater than in the overcast clouds. The high $q_{\mathrm{D}}$ is likely to increase the accretion and self-collection rates in POCs. Table 5 shows, however, that, in each POC case, higher $q_{\mathrm{D}}$ in quiescent clouds does not always translate to higher precipitation rates, which are estimated from the in situ 2DCmeasured drizzle size distribution averaged over the appropriate cloud type. As in the POC-overcast comparison, this discrepancy exists because much of the drizzle mass difference resides at the smaller sizes, which have a smaller influence on precipitation rate.

\section{Aerosol}

\subsection{Accumulation-mode aerosol}

Some of the macrophysical difference between the overcast and POC cloud characteristics are attributable to differences in inversion structure and LCL height. Many of the microphysical differences, such as differences in $N_{\mathrm{d}}$, are attributable to the low accumulation-mode aerosol concentrations $\left(N_{\mathrm{a}}\right)$ in POCs. The POC subcloud-layer $N_{\mathrm{a}}$ of $\sim$ $30 \mathrm{~cm}^{-3}$ (Table 4), as measured by the PCASP, is much lower than the typical $25-75$ th percentile range of $70-220 \mathrm{~cm}^{-3}$ (Allen et al., 2011) in the $80^{\circ} \mathrm{W}$ region during the VOCALSREx time period. $N_{\mathrm{a}}$ in the surrounding overcast regions range between 64 and $330 \mathrm{~cm}^{-3}$ across the five cases, similar to the REx-mean distribution near $80^{\circ} \mathrm{W}$, and are well correlated with $N_{\mathrm{d}}$ (Table 4). The cases (e.g., RF08) with higher $N_{\mathrm{a}}$ in the overcast region are related to hook features associated with localized offshore aerosol transport in the freetroposphere and boundary layer, described by George et al. (2013). The subcloud $N_{\mathrm{a}}$ in the POC is uncorrelated with $N_{\mathrm{a}}$ in the surrounding overcast and shows remarkable small variation $\left(24-40 \mathrm{~cm}^{-3}\right)$ across the five POC cases. If we extend the comparison to other previously observed POC cases (Sharon et al., 2006; Petters et al., 2006; Wood et al., 2008), the similarity in subcloud $N_{\mathrm{a}}$ still holds (Table 4). Spatially, across the overcast-to-POC transition, subcloud $N_{\mathrm{a}}$ gradually decreases over tens of kilometers across the transition (Fig. 2), whose gradients across the transition vary from case to case. Even within the POC, Fig. 2 and Table 4 show that subcloud $N_{\mathrm{a}}$ can spatially vary by more than $25 \%$.

Whereas we have mostly examined data collected during the level flight legs to examine horizontal gradients in $N_{\mathrm{a}}$, we use both the profiles and level flight legs to examine the vertical distribution of $N_{\mathrm{a}}$ (Fig. 7). In the RF06 case, Wood et al. (2011a) noted a layer of ultraclean air in the POC region where mean PCASP aerosol concentrations are considerably lower than $10 \mathrm{~cm}^{-3}$. We find that an ultraclean layer exists in all of the other POC cases examined during VOCALS. The ultraclean layers typically extend from roughly the stratocumulus cloud-base height to the inversion base, with a broad range of thicknesses (from $200 \mathrm{~m}$ for RF06 to $700 \mathrm{~m}$ for RF07). The concentrations in the ultraclean layer also vary from case to case, ranging from the very clean RF09 case, where a $400 \mathrm{~m}$ layer with concentrations $<1 \mathrm{~cm}^{-3}$ was observed, to the more polluted RF08 case, where concentrations mostly hovered around $5 \mathrm{~cm}^{-3}$ and those concentrations $<1 \mathrm{~cm}^{-3}$ were rarely observed. Concerning the structure of the ultraclean layer, with the exception of RF08, the vertical gradient in aerosol concentration is sharper at the inversion compared to the more gradual change from relatively well-mixed subcloud layer to the ultraclean layer.

\subsection{Aitken-mode aerosol}

Whereas $N_{\mathrm{a}}$ is much lower in the POC at all heights, the same is not true for concentrations of smaller aerosol particles. Past shipboard measurements (Kollias et al., 2004; Petters et al., 2006; Tomlinson et al., 2007; Wood et al., 2008) reported an increase in the number of Aitken-mode aerosols in the very clean regions of the POCs, suggesting that the low aerosol concentrations in the POC allow for the nucleation of Aitkenmode aerosols. Their growth to accumulation-mode sizes 
Table 5. In situ measurements of cloud and drizzle properties of active and quiescent clouds observed across the five POC cases. A $\overline{w^{\prime 2}}$ threshold of $0.1 \mathrm{~m}^{2} \mathrm{~s}^{-2}$ is used to categorize cloud measurements as either active or quiescent, except for the daytime flight RF13, where a threshold of $0.03 \mathrm{~m}^{2} \mathrm{~s}^{-2}$ is used. All active and quiescent values are averaged over in-cloud measurements, defined as measurements for which the combined liquid water mixing ratio from CDP and $2 \mathrm{DC}$ is greater than $0.03 \mathrm{~g} \mathrm{~kg}^{-1}$ or the liquid water mixing ratio as measured by the Gerber PV-100 Probe is greater than $0.03 \mathrm{~g} \mathrm{~kg}^{-1}$.

\begin{tabular}{llrrrrrrrr}
\hline Case & Cloud & $\begin{array}{r}\text { Length } \\
(\mathrm{km})\end{array}$ & $\begin{array}{r}\text { Fraction } \\
(\%)\end{array}$ & $\begin{array}{r}\overline{w^{\prime 2}} \\
\left(\mathrm{~m}^{2} \mathrm{~s}^{-2}\right)\end{array}$ & $\begin{array}{r}N_{\mathrm{d}} \\
\left(\mathrm{cm}^{-3}\right)\end{array}$ & $\begin{array}{r}N_{\mathrm{D}} \\
\left(\mathrm{L}^{-1}\right)\end{array}$ & $\begin{array}{r}q_{\mathrm{c}} \\
\left(\mathrm{g} \mathrm{kg}^{-1}\right)\end{array}$ & $\begin{array}{r}q_{\mathrm{D}} \\
\left(\mathrm{g} \mathrm{kg}^{-1}\right)\end{array}$ & $\begin{array}{r}R_{\text {in situ }} \\
\left(\mathrm{mm} \mathrm{d}^{-1}\right)\end{array}$ \\
\hline RF06 & Active & 32.5 & 14.6 & 0.70 & 21 & 280 & 0.29 & 0.22 & 24.0 \\
& Quiescent & 78.2 & 35.1 & 0.03 & 5 & 272 & 0.05 & 0.22 & 15.1 \\
\multirow{2}{*}{ RF07 } & Active & 2.0 & 3.3 & 0.17 & 5 & 233 & 0.07 & 0.09 & 3.5 \\
& Quiescent & 24.4 & 40.6 & 0.04 & 5 & 323 & 0.06 & 0.19 & 9.3 \\
& & & & & & & & & \\
RF08 & Active & 14.6 & 22.5 & 0.18 & 19 & 213 & 0.12 & 0.15 & 11.5 \\
& Quiescent & 23.6 & 36.3 & 0.05 & 9 & 274 & 0.08 & 0.16 & 7.9 \\
RF09 & Active & 5.2 & 4.3 & 0.55 & 26 & 49 & 0.15 & 0.02 & 2.1 \\
& Quiescent & 37.4 & 31.2 & 0.03 & 3 & 188 & 0.03 & 0.15 & 8.6 \\
RF13 & Active & 32.0 & 15.1 & 0.06 & 15 & 214 & 0.16 & 0.11 & 5.9 \\
& Quiescent & 52.5 & 24.8 & 0.01 & 4 & 307 & 0.06 & 0.16 & 9.9 \\
\hline
\end{tabular}

may potentially provide a source of cloud condensation nuclei (CCN) in the POC (Kazil et al., 2011). The Aitken-mode aerosol concentration is estimated from our C-130 observations as the difference between total aerosol concentrations for particles with diameter $>10 \mathrm{~nm}(\mathrm{CN})$ and those from the PCASP $(>100 \mathrm{~nm}$ ). From our observations of the five POC cases, no clear picture of enhanced or depleted Aitken-mode aerosols emerges. Subcloud Aitken-mode aerosol concentrations in the POC only increase for three of the five cases (RF06, RF08, and RF09; Table 4), and their concentrations do not correlate with subcloud $N_{\mathrm{a}}$. We also find that, except for the daytime RF13 flight, the concentration of Aitkenmode aerosols decreases in the ultraclean layer, where we expect the highest nucleation rates due to low aerosol surface concentrations. It must be noted that four of the POCs were sampled during the night, when photochemical production of nucleation mode precursor gases is absent. Whereas the processes that determine the sources and sinks of accumulationmode aerosols appear to have a clear vertical structure, the Aitken-mode aerosols appear to be modulated by a variety of processes that are not as well constrained across different POC cases.

\subsection{Accumulation-mode aerosol budget in POCs}

Although the relatively small variation between cases in POC subcloud $N_{\text {a }}$ could be coincidental, it certainly warrants attention. The similarity across different POCs indicates that the source and sink balance of accumulation-mode aerosols somehow gives rise to relatively constant concentrations. Such a stable equilibrium at low aerosol concentrations is suggested by the modeling study of Baker and Charlson (1990). The small spread between cases is surpris- ing given that the observations are strongly suggestive of a surface source of aerosols and that mean surface wind speeds vary between 5 and $11 \mathrm{~m} \mathrm{~s}^{-1}$ between cases. Surface aerosol fluxes from sea-salt flux parameterizations are strong functions of wind speed (e.g., de Leeuw et al., 2011).

If we assume that the primary source of aerosols in the POC is indeed the ocean surface, then a steady-state $\mathrm{CCN}$ concentration in the POC subcloud layer $\left(N_{\mathrm{S}}\right)$ can be estimated with the equation

$N_{\mathrm{s}}=N_{+}+\frac{F}{M_{\mathrm{Cu}}}$,

where $N_{+}$is the $\mathrm{CCN}$ concentration just above the subcloud layer; $F$ is the surface source of $\mathrm{CCN}$-sized aerosols; and $M_{\mathrm{Cu}}$ is the entrained mass flux into the subcloud layer from above, which keeps the surface layer partially coupled to the cloud layer in the POC. This must equal the cumulus mass flux out of the subcloud layer. In other words, the surface flux of $\mathrm{CCN}$ is balanced by the mixing of $\mathrm{CCN}$-depleted air into the top of the subcloud layer.

We may obtain estimates of $N_{+}, F$, and $M_{\mathrm{Cu}}$ to verify whether this balance equation applies to the observed POC cases. $N_{+}$is estimated as the mean PCASP aerosol concentration from the below cloud flight legs. $F$ is estimated using the sea-salt flux parameterization from Clarke et al. (2006) integrated over the same size range as that sampled by the PCASP. The $10 \mathrm{~m}$ mean wind speed $\left(u_{10}\right)$ that is needed for the calculation is estimated from the mean wind speed measured in the subcloud legs and assuming a log-wind profile with a surface roughness of $1.86 \times 10^{-4} \mathrm{~m}$ (Wood et al., 2011a). Because the parameterized aerosol flux has a dependence of $u_{10}^{3.41}$, an order of magnitude difference in fluxes exists between the low and high wind conditions (see Table 6). 

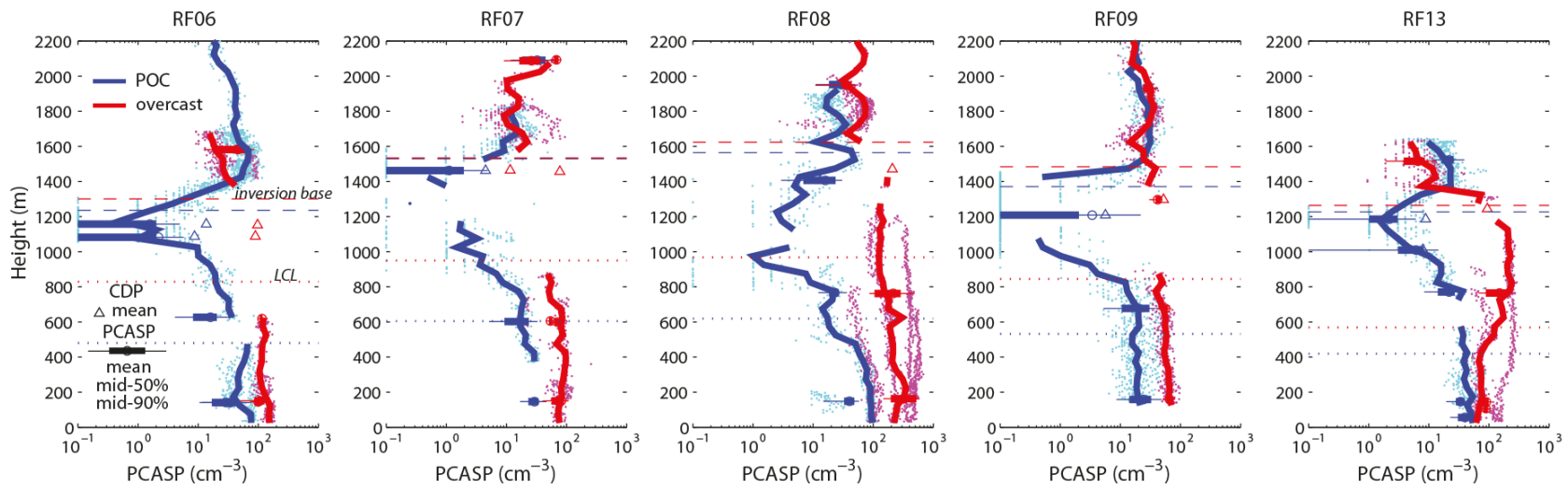

Figure 7. Profiles of PCASP aerosol concentration from the POC (blue) and overcast (red) region. Cyan (POC) and magenta (overcast) dots indicate individual data points from profiles flown in the two regions. Concentrations $<0.1 \mathrm{~cm}^{-3}$ are set at $0.1 \mathrm{~cm}^{-3}$ to allow for easier plotting on the log-scale abscissa. The thicker profile line indicates the median taken from the profile data. PCASP data from level flight legs are also included in the form of box-and-whisker plots. For reference, cloud-mean cloud droplet number concentrations from the CDP are shown as open triangles, mean inversion base heights calculated from profile measurements are shown as dashed lines, and mean lifting condensation levels calculated from subcloud flight legs are shown as dotted lines.

The cumulus mass flux $\left(M_{\mathrm{Cu}}\right)$ can be estimated from examining the water balance at the top of the subcloud layer. If we assume that the upward moisture flux in the cumulus clouds is balanced by precipitation rates, then $M_{\mathrm{Cu}}$ can be estimated as

$M_{\mathrm{Cu}}=\frac{R_{500}}{\Delta q} \rho$,

where $R_{500}$ is the precipitation rate at $500 \mathrm{~m} ; \Delta q$ is the moisture difference between cloudy and clear parcels at the top of the subcloud layer; and $\rho$ is the air density, which we assume to be $1 \mathrm{~kg} \mathrm{~m}^{-3}$. The precipitation rate at $500 \mathrm{~m}$ is chosen because this is the approximate height of the LCL (Table 3), which typically coincides with the height of the top of the subcloud layer. The estimated cumulus mass fluxes, reported in Table 6, range between 1.0 and $2.8 \mathrm{~cm} \mathrm{~s}^{-1}$.

Except in RF09, the estimated $F / M_{\mathrm{Cu}}$ is much smaller than the observed $N_{\mathrm{s}}-N_{+}$, inconsistent with the balance (Eq. 1). In addition to the simplicity of the budget in Eq. (1), there are several possible reasons for this discrepancy. First, determining an appropriate $N_{+}$is made difficult by the vertical gradient in $N_{\mathrm{a}}$ at the top of the subcloud layer, as evident in Fig. 7. Rather than decreasing abruptly at the top of the subcloud layer, $N_{\mathrm{a}}$ gradually decreases upward into the cloud layer. Second, we have neglected any other sources of CCN-sized aerosols, such as the growth of Aitken-mode aerosols to accumulation-mode sized particles. Third, other budget terms such as losses from precipitation scavenging of aerosols in the subcloud layer could be significant. What we can say from the values in Table 6 is that $F / M_{\mathrm{Cu}}$ can easily vary by more than a factor of 4 , and their variations do not correlate with $N_{\mathrm{s}}$ or $N_{\mathrm{s}}-N_{+}$. We are therefore left without an explanation to why the subcloud $N_{\mathrm{a}}$ in POC varies so weakly across different POC cases.

\section{Non-POC cases}

Two cases of cloud breaks which may appear as contenders for POCs, but which are excluded from our definition of POCs, are examined here. The first case of cloud break-up sampled during RF02 (18 October) and shown in Fig. 8a was sampled to the south of a hook-like cloud feature of enhanced $N_{\mathrm{d}}$ from the transport and entrainment from the free troposphere of anthropogenic aerosols (George et al., 2013). Despite the break in the cloud to the south of the hook feature, we do not identify this feature as a POC, because it lacks the microphysical change (a substantial increase in effective radius at its edges) that we associate with POCs. In situ observations show that, instead of a decrease in accumulationmode aerosols, there is a subsequent increase in subcloud $N_{\mathrm{a}}$ from $\sim 200$ to $\sim 300 \mathrm{~cm}^{-3}$ to the south. Likewise, the $N_{\mathrm{d}}$ increases from $\sim 100$ to $\sim 200 \mathrm{~cm}^{-3}$ (not shown). From the C-130 observation alone, however, we cannot determine the reason for the cloud break-up to the south. We do find that the inversion at approximately $1000 \mathrm{~m}$ around $83^{\circ} \mathrm{W}$ is anomalously low, and the decrease in cloud cell size to the south in the satellite visible imagery hints at a lowering of the inversion height to the south that might mean a lowering of cloud-top heights to the south.

The second case (Fig. 8b) corresponds to western edge of the stratocumulus cloud deck observed during RF04 (23 October), where large drizzle rates were observed. High radar reflectivities ( $>10 \mathrm{dBZ}$ ), representing heavy drizzle, cold pool formation, and an increase in cloud effective radius towards the edge of the cloud deck were observed in daytime satellite retrievals of this case, but no open cellular convection was observed beyond the edge of the overcast clouds, excluding this case from our definition of POCs. We also do not observe a decrease in $N_{\mathrm{a}}$ to the west of the break-up, although 
Table 6. Aerosol budget values. Values relevant to the aerosol budget of Eq. (1) are listed. Measured values include PCASP-sized aerosols from subcloud $\left(N_{\mathrm{S}}\right)$ and below cloud $\left(N_{+}\right)$flight legs as well as $\Delta q$, which is the mean difference in water (vapor + cloud) mixing ratio between cloudy and clear conditions measured in below cloud legs. The surface aerosol flux $(F)$ of PCASP-sized aerosols is estimated from the subcloud leg-mean wind speed (see Table 2$)$ using the parameterization from Clarke et al. (2006). POC-mean precipitation rate $\left(R_{500}\right)$ at $500 \mathrm{~m}$ is estimated from the radar reflectivity at $500 \mathrm{~m}$ using the $Z-R$ relationship proposed by Comstock et al. (2004) $\left(R\right.$ (mm $\mathrm{d}^{-1}$ ) $=2.01 Z^{0.77}$ ). The cumulus mass flux $M_{\mathrm{Cu}}$ is estimated using the relationship in Eq. (2).

\begin{tabular}{ccccccccc}
\hline Case & $\begin{array}{c}N_{\mathrm{s}} \\
\left(\mathrm{cm}^{-3}\right)\end{array}$ & $\begin{array}{c}N_{+} \\
\left(\mathrm{cm}^{-3}\right)\end{array}$ & $\begin{array}{c}N_{\mathrm{s}}-N_{+} \\
\left(\mathrm{cm}^{-3}\right)\end{array}$ & $\begin{array}{c}F \\
\left(\times 10^{3} \mathrm{~m}^{2} \mathrm{~s}^{-2}\right)\end{array}$ & $\begin{array}{c}R_{500} \\
\left(\mathrm{~mm} \mathrm{~d}^{-1}\right)\end{array}$ & $\begin{array}{c}\Delta q \\
\left(\mathrm{~g} \mathrm{~kg}^{-1}\right)\end{array}$ & $\begin{array}{c}M_{\mathrm{Cu}} \\
\left(\mathrm{cm} \mathrm{s}^{-1}\right)\end{array}$ & $\begin{array}{c}F / M_{\mathrm{Cu}} \\
\left(\mathrm{cm}^{-3}\right)\end{array}$ \\
\hline RF06 & 32 & 16 & 16 & 230 & 2.2 & 0.9 & 2.8 & 8.1 \\
RF07 & 29 & 18 & 11 & 70 & 2.8 & 1.2 & 2.7 & 2.6 \\
RF08 & 40 & 23 & 17 & 62 & 2.7 & 1.1 & 2.8 & 2.2 \\
RF09 & 24 & 20 & 4 & 49 & 0.8 & 0.9 & 1.0 & 4.8 \\
RF13 & 37 & 12 & 15 & 13 & 1.5 & 0.8 & 2.2 & 0.6 \\
\hline
\end{tabular}

a decrease in aerosols in the clear region is not part of the definition of POCs in this study. This suggests that higher precipitation rates at the edges of overcast clouds do not always indicate that the strong aerosol-cloud-precipitation interactions that we observe in POCs are the cause for the break-up in the clouds.

\section{Discussion and conclusions}

Five pockets of open cells (POCs) sampled during VOCALSREx by the NSF/NCAR C-130 are comprehensively compared with their surrounding overcast regions. Freetropospheric water vapor and temperature, sea surface temperatures, inversion height, and near-surface winds were not found to differ appreciably in the POCs compared with the surrounding overcast stratocumulus areas, and are not very different from the REx-mean conditions in the sampled regions. This latter fact indicates that POCs can be maintained under typical large-scale meteorological conditions found over the southeast Pacific.

A consistent feature of POCs is the presence of heavy drizzle rates $(>10 \mathrm{dBZ})$ and associated cold pools, which are largely absent in the surrounding overcast regions. All five of the observed POCs also contain both active - cumuliform and quiescent - stratiform clouds. Active clouds associated with cumulus-like convection make up a smaller proportion of the cloud cover $(\mathrm{CF}<25 \%)$ in the POC and have larger cloud droplet number concentrations $\left(N_{\mathrm{d}}\right)$ and larger cloud water mixing ratios $\left(q_{\mathrm{c}}\right)$. Although collisioncoalescence rates are expected to be high in the active clouds, their comparatively high $N_{\mathrm{d}}\left(20 \mathrm{~cm}^{-3}\right)$ suggests that active clouds loft relatively aerosol-rich subcloud-layer air to the cloud layer and detrain some of this aerosol into surrounding quiescent clouds, which cover more of the POCs and are characterized by very low $N_{\mathrm{d}}\left(<10 \mathrm{~cm}^{-3}\right)$ and high drizzle water mixing ratio $\left(q_{\mathrm{D}}\right)$. We cannot determine from these observations whether quiescent clouds are spatial extensions of active cells, as in the trailing stratiform region of larger mesoscale convective systems; are remnants of decaying ac- tive clouds; or are formed in situ. Snapshots of POC cloud fields from LES studies of Berner et al. (2011) and Kazil et al. (2011) suggest that quiescent clouds are spatial extensions of active cumulus clouds, but a closer examination of the time evolution of quiescent clouds will be necessary to resolve this issue.

The efficiency of the in-cloud coalescence scavenging in cleaning out accumulation-mode aerosols in POCs is most evident in the apparently omnipresent ultraclean layer observed across all five POCs. The presence of the ultraclean layer, combined with the low values of vertical velocity variance in the cloud layer within the POC and increased aerosol concentrations at lower altitudes, also strongly suggests that the surface source of accumulation-mode aerosols, and hence of cloud condensation nuclei, is more important than a freetropospheric source. In addition, we find that the spread of mean subcloud-layer accumulation-mode aerosol concentration $\left(N_{\mathrm{a}}\right)$ in the POCs is remarkably narrow, with a mean value $\left(\sim 30 \mathrm{~cm}^{-3}\right)$ that is close to values found in previously studied cases from other locations and times (Sharon et al., 2006; Petters et al., 2006; Wood et al., 2008). This mean value appears to be insensitive to $N_{\mathrm{a}}$ in the surrounding overcast region, suggesting that the factors controlling the aerosol budget in the POC are independent of those in the surrounding overcast.

The factors that determine the $N_{\mathrm{a}}$ budget in the POC subcloud layer in the simple aerosol budget of Eq. (1) are quantified in Table 6 . We find that our simple budget calculation does not shed light on explaining the narrow range of observed subcloud $N_{\mathrm{a}}$ in POCs. Instead, it leaves us with a puzzle as to how the narrow range of $N_{\mathrm{a}}$ exists when the surface source of aerosols can differ by more than an order of magnitude. Because high-resolution cloud-resolving model studies with interactive aerosols also show similar accumulationmode aerosol concentrations in the subcloud layer (Kazil et al., 2011; Berner et al., 2013), further modeling studies with variable surface source functions may help shed light on whether there is indeed a physical explanation for the similarity. 
(a)

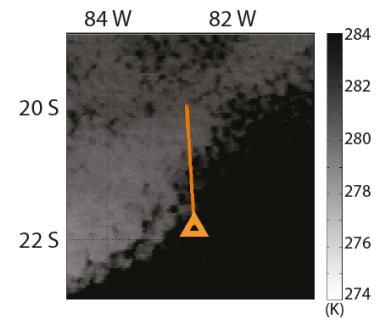

(b)

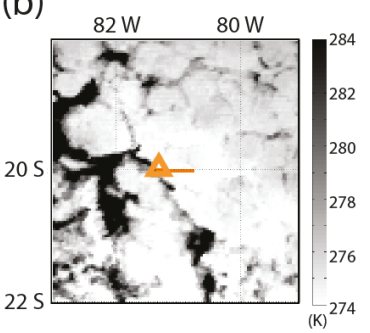

RF02

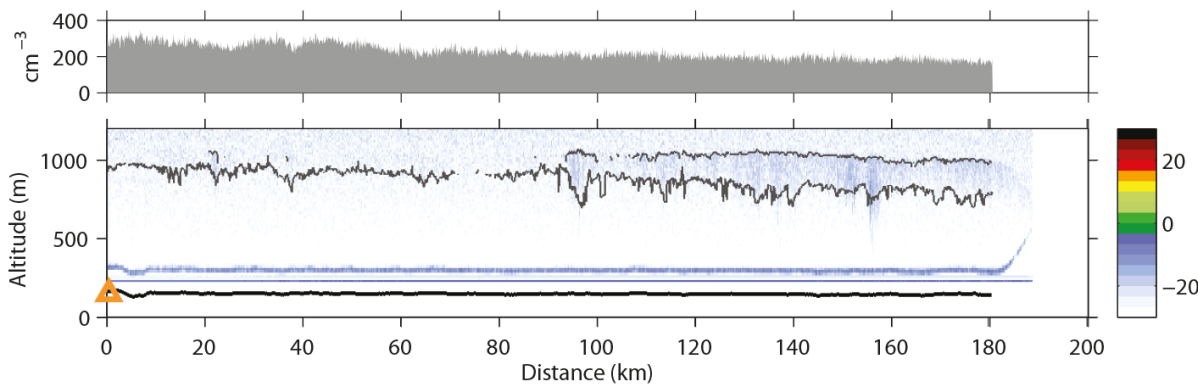

RF04

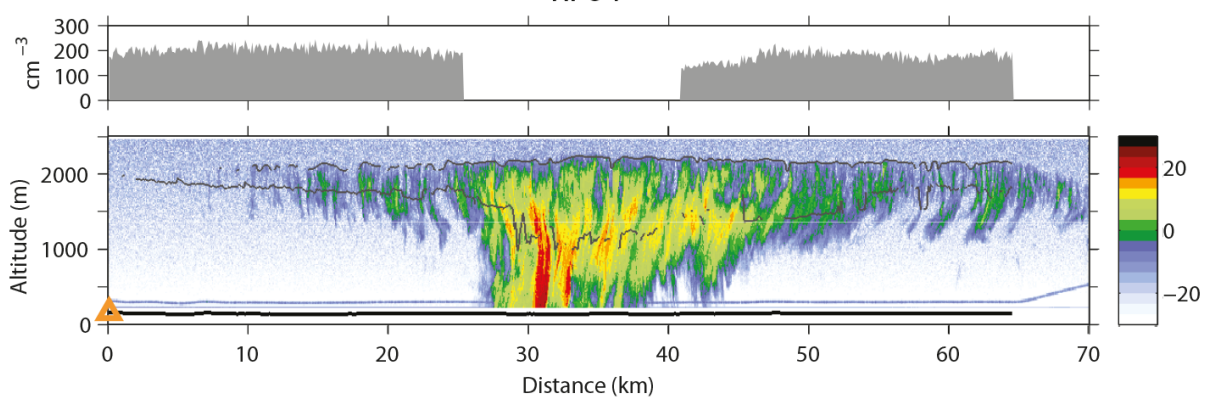

Figure 8. (a) C-130 subcloud flight track from RF02 (18 October 2008 16:50 UTC) is overlaid on GOES-10 infrared satellite imagery taken at the same time. As in Fig. 2, the top right panel shows the in situ PCASP aerosol concentrations at $\sim 150 \mathrm{~m}$. The bottom right panel shows the WCR reflectivity with the flight altitude indicated in bold black and the WCR/WCL-derived cloud-top height and cloud-base height indicated in gray. (b) Same as (a) but for a subcloud flight track from RF04 (23 October 2008 10:20 UTC).

Finally, it is important to state that while this study informs of the mechanisms involved in POC maintenance, it does not inform of the mechanisms by which POCs form. Previous modeling studies have looked at the transition from closedcell to open-cell convection mediated by cold pool formation (Wang et al., 2010), cloud-aerosol interactions (Kazil et al., 2011), or high liquid water path (Wang et al., 2010; Berner et al., 2013). Observational studies have noted the possible role of gravity waves (Allen et al., 2013) or larger cloud droplet sizes (Wood et al., 2008) in POC formation, but widespread observational data are still lacking, largely because POCs preferentially form overnight (Wood et al., 2008). A concerted effort to combine satellite retrievals and regional models will likely be necessary to pin down the key factors that contribute to POC formation; in a future paper, we will present a satellite-based study of the evolution of the five VOCALS-REx POC cases prior to the in situ aircraft observations.

Acknowledgements. Funding for this work was provided by NSF grants ATM-0745702 and AGS-1242639 and NASA MAP grant NNX09AH73G. The authors thank the scientists, staff, ground crew, and aircrew at the NCAR Research Aviation Facility, as well as the $\mathrm{C}-130$ scientists who were instrumental in the collection of the data analyzed here. The $\mathrm{C}-130$ data were provided by NCAR/EOL under sponsorship of the National Science Foundation: http://data.eol.ucar.edu/.
We thank the two anonymous reviewers for the constructive comments to help improve the paper.

Edited by: R. Krejci

\section{References}

Abel, S. J., Walters, D. N., and Allen, G.: Evaluation of stratocumulus cloud prediction in the Met Office forecast model during VOCALS-REx, Atmos. Chem. Phys., 10, 10541-10559, doi:10.5194/acp-10-10541-2010, 2010.

Allen, G., Coe, H., Clarke, A., Bretherton, C., Wood, R., Abel, S. J., Barrett, P., Brown, P., George, R., Freitag, S., McNaughton, C., Howell, S., Shank, L., Kapustin, V., Brekhovskikh, V., Kleinman, L., Lee, Y.-N., Springston, S., Toniazzo, T., Krejci, R., Fochesatto, J., Shaw, G., Krecl, P., Brooks, B., McMeeking, G., Bower, K. N., Williams, P. I., Crosier, J., Crawford, I., Connolly, P., Allan, J. D., Covert, D., Bandy, A. R., Russell, L. M., Trembath, J., Bart, M., McQuaid, J. B., Wang, J., and Chand, D.: South East Pacific atmospheric composition and variability sampled along $20^{\circ} \mathrm{S}$ during VOCALS-REx, Atmos. Chem. Phys., 11, 5237-5262, doi:10.5194/acp-11-5237-2011, 2011.

Allen, G., Vaughan, G., Toniazzo, T., Coe, H., Connolly, P., Yuter, S. E., Burleyson, C. D., Minnis, P., and Ayers, J. K.: Gravity-wave-induced perturbations in marine stratocumulus. Q. J. Roy. Meteor. Soc., 139, 32-45, doi:10.1002/qj.1952, 2013.

Atkinson, B. and Zhang, J. W.: Mesoscale shallow convection in the atmosphere, Rev. Geophys., 34, 403-431, doi:10.1029/96RG02623, 1996. 
Baker, M. and Charlson, R. J.: Bistability of CCN concentrations and thermodynamics in the cloud-topped boundary layer, Nature., 345, 142-145, doi:10.1038/345142a0, 1990.

Berner, A. H., Bretherton, C. S., and Wood, R.: Large-eddy simulation of mesoscale dynamics and entrainment around a pocket of open cells observed in VOCALS-REx RF06, Atmos. Chem. Phys., 11, 10525-10540, doi:10.5194/acp-11-10525-2011, 2011.

Berner, A. H., Bretherton, C. S., Wood, R., and Muhlbauer, A.: Marine boundary layer cloud regimes and POC formation in a CRM coupled to a bulk aerosol scheme, Atmos. Chem. Phys., 13, 12549-12572, doi:10.5194/acp-13-12549-2013, 2013.

Bretherton, C. S., Uttal, T., Fairall, C. W., Yuter, S. E.,Weller, R. A., Baumgardner, D., Comstock, K., and Wood, R.: The EPIC 2001 stratocumulus study, B. Am. Meteorol. Soc., 85, 967-977, doi:10.1175/BAMS-85-7-967, 2004.

Bretherton, C. S., Wood, R., George, R. C., Leon, D., Allen, G., and Zheng, X.: Southeast Pacific stratocumulus clouds, precipitation and boundary layer structure sampled along $20^{\circ} \mathrm{S}$ during VOCALS-REx, Atmos. Chem. Phys., 10, 10639-10654, doi:10.5194/acp-10-10639-2010, 2010.

Caldwell, P., and Bretherton, C. S.: Large Eddy simulation of the diurnal cycle in Southeast Pacific stratocumulus, J. Atmos. Sci., 66, 432-449, doi:10.1175/2008JAS2785.1, 2009.

Clarke, A. D., Owens, S. R., and Zhou, J.: An ultrafine sea-salt flux from breaking waves: implications for cloud condensation nuclei in remote marine atmosphere, J. Geophys. Res., 111, 06202, doi:10.1029/2005JD006565, 2006.

Clarke, A., McNaughton, C., Kapustin, V., Shinozuka, Y., Howell, S., Dibb, J., Zhou, J., Anderson, B., Brekhovskikh, V., Turner, H., and Pinkerton, M.: Biomass burning and pollution aerosol over North America: organic components and their influence on spectral optical properties and humidification response, J. Geophys. Res., 112, D12S18, doi:10.1029/2006JD007777, 2007.

Comstock, K. K., Wood, R., Yuter, S. E., and Bretherton, C. S.: Reflectivity and rain rate in and below drizzling stratocumulus, Q. J. Roy. Meteor. Soc., 130, 2891-2918, doi:10.1256/qj.03.187, 2004.

Comstock, K. K., Yuter, S. E., Wood, R., and Bretherton, C. S.: The three-dimensional structure and kinematics of drizzling stratocumulus, Mon. Weather Rev., 135, 3767-3784, doi:10.1175/2007MWR1944.1, 2007.

Cui, Z., Gadian, A., Blyth, A., Crosier, J., and Crawford, I.: Observations of the variation in aerosol and cloud microphysics along the $20^{\circ} \mathrm{S}$ transect on 13 November 2008 during VOCALS-REx, J. Atmos. Sci., doi:10.1175/JAS-D-13-0245.1, in press, 2014.

de Leeuw, G., Andreas, E. L., Anguelova, M. D., Fairall, C. W., Lewis, E. R., O'Dowd, C., Schulz, M., and Schwartz, S. E.: Production flux of sea spray aerosol, Rev. Geophys., 49, RG2001, doi:10.1029/2010RG000349, 2011.

de Szoeke, S. P., Yuter, S., Mechem, D., Fairall, C. W., Burleyson, C. D., and Zuidema, P.: Observations of stratocumulus clouds and their effect on the Eastern Pacific surface heat budget along $20^{\circ} \mathrm{S}$, J. Climate, 25, 8542-8567, doi:10.1175/JCLI-D-11$00618.1,2012$.

Garay, M. J., Davies, R., Averill, C., and Westphal, J. A.: Actinoform clouds: overlooked examples of cloud self-organization at the mesoscale, B. Am. Meteorol. Soc., 85, 1585-1594, doi:10.1175/BAMS-85-10-1585, 2004.
George, R. C. and Wood, R.: Subseasonal variability of low cloud radiative properties over the southeast Pacific Ocean, Atmos. Chem. Phys., 10, 4047-4063, doi:10.5194/acp-10-4047-2010, 2010.

George, R. C., Wood, R., Bretherton, C. S., and Painter, G.: Development and impact of hooks of high droplet concentration on remote southeast Pacific stratocumulus, Atmos. Chem. Phys., 13, 6305-6328, doi:10.5194/acp-13-6305-2013, 2013.

Jones, C. R., Bretherton, C. S., and Leon, D.: Coupled vs. decoupled boundary layers in VOCALS-REx, Atmos. Chem. Phys., 11, 7143-7153, doi:10.5194/acp-11-7143-2011, 2011.

Kazil, J., Wang, H., Feingold, G., Clarke, A. D., Snider, J. R., and Bandy, A. R.: Modeling chemical and aerosol processes in the transition from closed to open cells during VOCALS-REx, Atmos. Chem. Phys., 11, 7491-7514, doi:10.5194/acp-11-74912011, 2011.

Klein, S. A. and Hartmann, D. L.: The seasonal cycle of low stratiform clouds, J. Climate, 6, 1587-1606, doi:10.1175/15200442(1993)006<1587:TSCOLS>2.0.CO;2, 1993.

Kollias, P., Fairall, C. W., Zuidema, P., Tomlinson, J., and Wick, G. A.: Observations of marine stratocumulus in SE Pacific during the PACS 2003 cruise, Geophys. Res. Lett., 31, L22110, doi:10.1029/2004GL020751, 2004.

Leon, D. C., Wang, Z., and Liu, D.: Climatology of drizzle in marine boundary layer clouds based on 1 year of data from CloudSat and Cloud-Aerosol Lidar and Infrared Pathfinder Satellite Observations (CALIPSO), J. Geophys. Res., 113, D00A14, doi:10.1029/2008JD009835, 2008.

Martin, G., Johnson, D., and Spice, A.: The measurement and parameterization of effective radius of droplets in warm stratocumulus clouds, J. Atmos. Sci., 51, 1823-1842, doi:10.1175/15200469(1994)051<1823:TMAPOE>2.0.CO;2, 1994.

Mechem, D. B. and Kogan, Y. L.: Simulating the transition from drizzling marine stratocumulus to boundary layer cumulus with a mesoscale model, Mon. Weather Rev., 131, 2342-2360, 2003.

Mechoso, C. R., Wood, R., Weller, R., Bretherton, C. S., Clarke, A. D., Coe, H., Fairall, C., Farrar, J. T., Feingold, G., Garreaud, R., Grados, C., McWilliams, J., de Szoeke, S. P., Yuter, S. E., and Zuidema, P.: Ocean-cloud-atmosphere-land interactions in the southeastern Pacific: the VOCALS program, B. Am. Meteorol. Soc., 95, 357-375, doi:10.1175/BAMS-D-1100246.1, 2014.

Muhlbauer, A., McCoy, I. L., and Wood, R.: Climatology of stratocumulus cloud morphologies: microphysical properties and radiative effects, Atmos. Chem. Phys. Discuss., 14, 6981-7023, doi:10.5194/acpd-14-6981-2014, 2014.

Petters, M. D., Snider, J. R., Stevens, B., Vali, G., Faloona, I., and Russell, L. M.: Accumulation-mode aerosol, pockets of open cells, and particle nucleation in the remote subtropical Pacific marine boundary layer, J. Geophys. Res., 111, D02206, doi:10.1029/2004JD005694, 2006.

Saide, P. E., Spak, S. N., Carmichael, G. R., Mena-Carrasco, M. A., Yang, Q., Howell, S., Leon, D. C., Snider, J. R., Bandy, A. R., Collett, J. L., Benedict, K. B., de Szoeke, S. P., Hawkins, L. N., Allen, G., Crawford, I., Crosier, J., and Springston, S. R.: Evaluating WRF-Chem aerosol indirect effects in Southeast Pacific marine stratocumulus during VOCALS-REx, Atmos. Chem. Phys., 12, 3045-3064, doi:10.5194/acp-12-3045-2012, 2012. 
Savic-Jovcic, V. and Stevens, B.: The structure and mesoscale organization of precipitating stratocumulus, J. Atmos. Sci., 65, 15871605, doi:10.1175/2007JAS2456.1, 2008.

Sharon, T. M., Albrecht, B. A., Jonsson, H. H., Minnis, P., Khaiyer, M. M., van Reken, T. M., Seinfeld, J., and Flagan, R.: Aerosol and cloud microphysical characteristics of rifts and gradients in maritime stratocumulus clouds, J. Atmos. Sci., 63, 983-997, doi:10.1175/JAS3667.1, 2006.

Smith, W. L., Knuteson, R. O., Revercomb, H. E., Feltz, W., Howell, H. B., Menzel, W. P., Nalli, N. R., Brown, O., Brown, J., Minnett, P., and Walter. M.: Observations of the Infrared Radiative Properties of the Ocean- Implications for the Measurement of Sea Surface Temperature via Satellite Remote Sensing, B. Am. Meteorol. Soc., 77, 41-51, doi:10.1175/15200477(1996)077<0041:OOTIRP>2.0.CO;2, 1996.

Stevens, B., Vali, G., Comstock, K., Wood, R., Van Zanten, M. C., Austin, P. H., Bretherton, C. S., and Lenschow, D. H.: Pockets of open cells and drizzle in marine stratocumulus, B. Am. Meteorol. Soc., 86, 51-57, doi:10.1175/BAMS-86-1-51, 2005.

Terai, C. R. and Wood, R.: Aircraft observations of cold pools under marine stratocumulus, Atmos. Chem. Phys., 13, 9899-9914, doi:10.5194/acp-13-9899-2013, 2013.

Terai, C. R., Wood, R., Leon, D. C., and Zuidema, P.: Does precipitation susceptibility vary with increasing cloud thickness in marine stratocumulus?, Atmos. Chem. Phys., 12, 4567-4583, doi:10.5194/acp-12-4567-2012, 2012.

Tomlinson, J. M., Li, R., and Collins, D. R.: Physical and chemical properties of the aerosol within the southeastern Pacific marine boundary layer, J. Geophys. Res., 112, D12211, doi:10.1029/2006JD007771, 2007.

Turton, J. D. and Nicholls, S.: A study of the diurnal variation of stratocumulus using a multiple mixed layer model, Q. J. Roy. Meteor. Soc., 113, 969-1009, doi:10.1002/qj.49711347712, 1987.

Toniazzo, T., Abel, S. J., Wood, R., Mechoso, C. R., Allen, G., and Shaffrey, L. C.: Large-scale and synoptic meteorology in the south-east Pacific during the observations campaign VOCALSREx in austral Spring 2008, Atmos. Chem. Phys., 11, 49775009, doi:10.5194/acp-11-4977-2011, 2011.

Van Zanten, M. C. and Stevens, B.: Observations of the structure of heavily precipitating marine stratocumulus, J. Atmos. Sci., 62, 4327-4342, 2005.

Wang, H. and Feingold, G.: Modeling mesoscale cellular structure and drizzle in marine stratocumulus, Part I: Impact of drizzle on the formation and evolution of open cells, J. Atmos. Sci., 66, 3237-3256, doi:10.1175/2009JAS3022.1, 2009a.
Wang, H. and Feingold, G.: Modeling mesoscale cellular structure and drizzle in marine stratocumulus, Part II: The microphysics and dynamics of the boundary region between open and closed cells, J. Atmos. Sci., 66, 3257-3275, doi:10.1175/2009JAS3120.1, 2009b.

Wang, H., Feingold, G., Wood, R., and Kazil, J.: Modelling microphysical and meteorological controls on precipitation and cloud cellular structures in Southeast Pacific stratocumulus, Atmos. Chem. Phys., 10, 6347-6362, doi:10.5194/acp-10-6347-2010, 2010.

Wood, R. and Hartmann, D. L.: Spatial variability of liquid water path in marine low cloud: the importance of mesoscale cellular convection. J. Climate, 19, 1748-1764, doi:10.1175/JCLI3702.1, 2006.

Wood, R., Comstock, K. K., Bretherton, C. S., Cornish, C., Tomlinson, J., Collins, D. R., and Fairall, C.: Open cellular structure in marine stratocumulus sheets, J. Geophys. Res., 113, D12207, doi:10.1029/2007JD009596, 2008.

Wood, R., Bretherton, C. S., Leon, D., Clarke, A. D., Zuidema, P., Allen, G., and Coe, H.: An aircraft case study of the spatial transition from closed to open mesoscale cellular convection over the Southeast Pacific, Atmos. Chem. Phys., 11, 2341-2370, doi:10.5194/acp-11-2341-2011, 2011a.

Wood, R., Mechoso, C. R., Bretherton, C. S., Weller, R. A., Huebert, B., Straneo, F., Albrecht, B. A., Coe, H., Allen, G., Vaughan, G., Daum, P., Fairall, C., Chand, D., Gallardo Klenner, L., Garreaud, R., Grados, C., Covert, D. S., Bates, T. S., Krejci, R., Russell, L. M., de Szoeke, S., Brewer, A., Yuter, S. E., Springston, S. R., Chaigneau, A., Toniazzo, T., Minnis, P., Palikonda, R., Abel, S. J., Brown, W. O. J., Williams, S., Fochesatto, J., Brioude, J., and Bower, K. N.: The VAMOS Ocean-Cloud-Atmosphere-Land Study Regional Experiment (VOCALS-REx): goals, platforms, and field operations, Atmos. Chem. Phys., 11, 627-654, doi:10.5194/acp-11-627-2011, 2011b.

Yang, Q., Gustafson Jr., W. I., Fast, J. D., Wang, H., Easter, R. C., Morrison, H., Lee, Y.-N., Chapman, E. G., Spak, S. N., and Mena-Carrasco, M. A.: Assessing regional scale predictions of aerosols, marine stratocumulus, and their interactions during VOCALS-REx using WRF-Chem, Atmos. Chem. Phys., 11, 11951-11975, doi:10.5194/acp-11-11951-2011, 2011.

Zuidema, P., Leon, D., Pazmany, A., and Cadeddu, M.: Aircraft millimeter-wave passive sensing of cloud liquid water and water vapor during VOCALS-REx, Atmos. Chem. Phys., 12, 355-369, doi:10.5194/acp-12-355-2012, 2012. 